\title{
SURVEY OF USERS OF THE USGS STREAM- GAGING NETWORK IN IOWA, 1996
}

by Edward E. Fischer

\section{U.S. GEOLOGICAL SURVEY}

Open-File Report 96-185

Prepared in cooperation with the IOWA HIGHWAY RESEARCH BOARD (IOWA DOT Research Project HR-383) 


\section{U.S. DEPARTMENT OF THE INTERIOR BRUCE BABBITT, Secretary \\ U.S. GEOLOGICAL SURVEY \\ GORDON P. EATON, Director}

For additional information write to:

District Chief

U.S. Geological Survey, WRD

Room 269 Federal Building

400 South Clinton Street

lowa City, lowa 52244
Copies of this report can be purchased from:

U.S. Geological Survey Earth Science Information Center Open-File Reports Section Box 25286, Denver Federal Center Denver, Colorado 80225 


\section{CONTENTS}

Abstract

Introduction

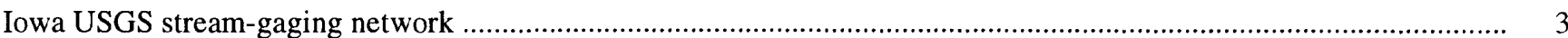

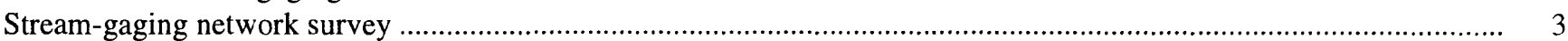

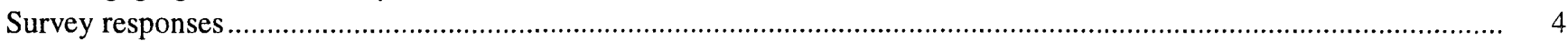

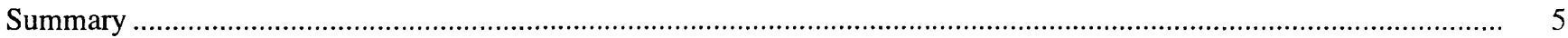

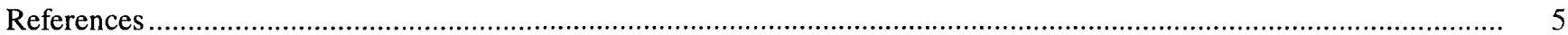

\section{FIGURES}

1. Map showing locations of USGS stream-gaging network stations in Iowa

2.-4. Histograms of:

2. Number of respondents per station that use streamflow data, Iowa USGS stream-gaging network survey

3. Number of streamflow-data-use categories indicated per station, Iowa USGS stream-gaging network survey

4. Sum of streamflow-data-use categories indicated per station, Iowa USGS stream-gaging network survey

\section{TABLES}

1.-4. Tabulation of responses to the Iowa USGS stream-gaging network survey with stations listed by:

1. County

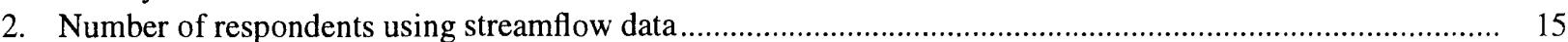

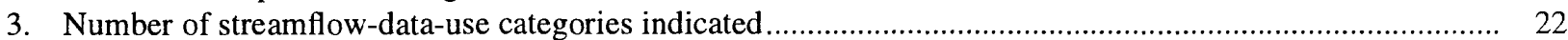

4. Sum of streamflow-data-use categories indicated................................................................................... 29 


\title{
Survey of Users of the USGS Stream-Gaging Network in lowa, 1996
}

\author{
By Edward E. Fischer
}

\section{ABSTRACT}

A survey was sent to over 200 Federal, State, and local agencies that might use streamflow data collected by the U.S. Geological Survey in Iowa. A total of 181 forms were returned and 112 agencies indicated that they use streamflow data. The responses show that streamflow data from the Iowa USGS stream-gaging network, which in 1996 is composed of 117 stations, are used by many agencies for many purposes and that many stations provide streamflow data that fulfill a variety of joint purposes. The median number of respondents per station that use data from the station was 6 and the median number of data-use categories indicated per station was 9 . The survey results can be used by agencies that fund the Iowa USGS stream-gaging network to help them decide which stations to continue to support if it becomes necessary to reduce the size of the stream-gaging network.

\section{INTRODUCTION}

The U.S. Geological Survey (USGS) streamgaging network in Iowa has evolved over the last 94 years as a result of many different needs for streamflow data. Because of the varied needs, the gaging stations do not comprise a network in the purest sense. Data collected at one station or group of stations in the network are intended to answer different questions than data collected at other stations. Rather, the network is an amalgam of many individual networks with different purposes and sources of funding. Fortunately, many USGS stations provide data that are useful for purposes other than that for which the station was originally installed (Wahl and Crippen, 1984, p. 1). The joint purposes that many stations consequently fulfill for the many users of streamflow data comprise a complex web of intertwined priorities.
The USGS is the primary Federal agency responsible for the collection of the Nation's streamflow data. The first Federal appropriations to the USGS for collecting streamflow data in Iowa were allocated in 1902. The stream-gaging network at that time comprised 10 stations (Burmeister and Lara, 1984, p. 4). Currently (1996), Federal appropriations to the USGS are applied to the operation and maintenance of 78 of 117 stations that compose the Iowa stream-gaging network. Other Federal, State, and local agencies provide the balance of the funds required to operate the network.

Budget constraints might require reductions in the number of stations in the network in the future. Using each station in the network, therefore, to satisfy as many joint purposes as possible becomes increasingly important. One of the tasks in fulfilling joint purposes is to determine what the various uses of streamflow data are for each station and who uses the data. While the sponsoring agency's purpose for the installation of a station is known, the streamflow data that are collected often are used by other agencies for other purposes. It is impracticable to identify completely all of the uses and users of the data because streamflow data collected by the USGS are in the public domain. It is possible, however, to develop a broad picture of many of the users and for what purposes the data are used.

This report presents the results of a survey that sought to determine who uses Iowa USGS streamflow data and for what purposes the data are used. The results can be used by agencies that fund the streamgaging network to help them decide which stations to continue to support if it becomes necessary to reduce the size of the network. This report does not suggest which stations to discontinue should it become necessary to reduce the size of the network, it does not consider the minimum size of the network that is required to maintain a specified level of quality for a particular streamflow-data need, nor does it advocate one category of data-use over another. 


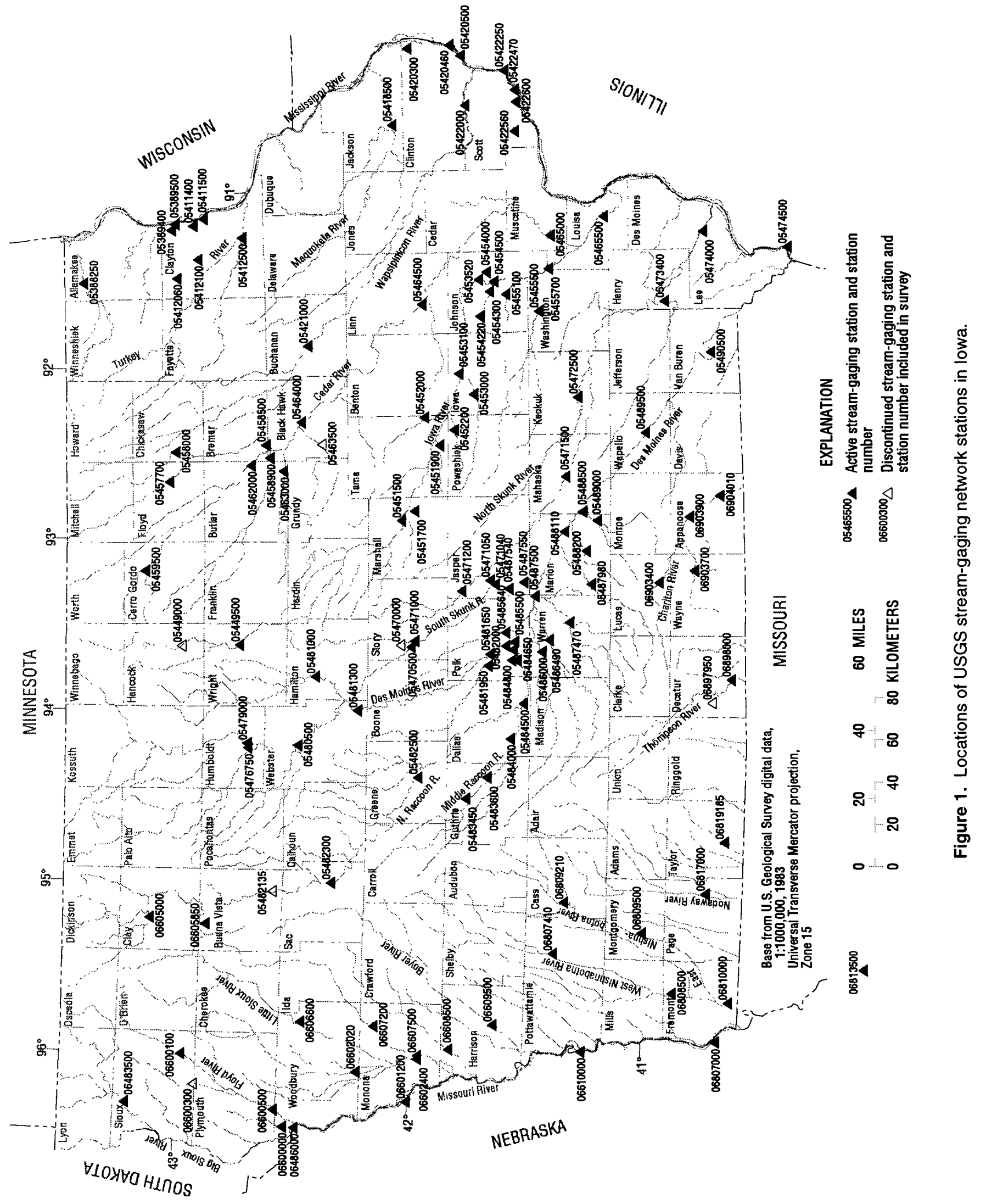




\section{IOWA USGS STREAM-GAGING NETWORK}

The current (1996) USGS stream-gaging network in Iowa is composed of 117 stations (fig. 1), which are funded by 27 different Federal, State, and local agencies. Nearly all of the stations are equipped with satellite and (or) telephone communications links to the data-storage computer. Gaging stations equipped with satellite links generally transfer data to the computer once every 4 hours. The stations equipped only with telephone links transfer data at least once each day. Most of the stations connected by telephone can be queried at any time for the current river stage. Streamflow data from 20 stations in the Iowa USGS network are available on the Internet communications network as soon as the data have been processed by the computer.

Streamflow data are published annually in U.S. Geological Survey Water Resources Data reports. Generally, streamflow data are published as daily mean values, which are the averages of the instantaneous values collected in a 24 -hour period. The location, drainage area, length of streamflow record, selected streamflow statistics, and other information about the gaging-station are included with the data. The annual water-data reports also include data such as sediment transport measurements, water-quality measurements, and ground-water levels from selected sites.

\section{STREAM-GAGING NETWORK SURVEY}

To develop a broad picture of who uses Iowa USGS streamflow data and for what purposes they use the data, a survey was sent to over 200 Federal, State, county, and municipal agencies that are either known users or possible users. The survey asked the recipients to identify which gaging stations provided data to their organizations and to specify the use or uses of the data. A postage-paid return envelope was included with the survey; the recipients were asked to return the forms regardless of whether they use streamflow data.

A list of the stations in the USGS stream-gaging network was included with the survey. The stations were identified by their USGS station identification number and location (for an explanation of station identification number, see May and others, 1995, p. 2526). The stations were listed alphabetically by county. So that recipients could answer the survey more easily, each station also was identified with a unique, simpli- fied code derived from the county in which it is located and the number of stations in the county. (The simplified codes are not reproduced in this report.) The list of stations was compiled during Federal Fiscal Year 1995 (which ended September 30, 1995) and included six stations that were discontinued during that fiscal year. Although those six stations are no longer active, responses regarding them are included in this report.

The categories of data-use and the category descriptions that were included in the survey are listed below. The categories were selected based on known streamflow-data uses.

Flood warning -- streamflow data provide information for flood warning and (or) flood forecasting.

Regulatory requirement -- streamflow data fulfill State or Federal regulatory requirements.

Water-quality monitoring -- streamflow data are used for the interpretation of water-quality and (or) sediment data.

Wastewater treatment plant operation -- streamflow data are used in the operation of a wastewater treatment facility.

Reservoir operation -- streamflow data are used in the operation of a reservoir or water-supply facility.

Minimum flow monitoring -- streamflow data are used to monitor minimum streamflows.

Long-term record/trend analyses -- streamflow data are used to monitor hydrologic trends in streamflows and geomorphologic trends in stream channels.

Regional hydrology -- streamflow data are used to develop regional relations between watershed and streamflow characteristics.

Streamflow modeling -- streamflow data are used as input for streamflow models.

Special project -- streamflow data are used for a particular research or water-investigation study.

Public information -- streamflow data are used to provide information to the general public.

Other uses -- streamflow data are used for a need not included in any of the other categories. 
The survey was mailed beginning November 1 , 1995. Forms initially were sent to the U.S. Army Corps of Engineers (St. Paul, Rock Island, Omaha, and Kansas City Districts), the National Weather Service (Johnston, Iowa; Davenport, Iowa; Valley, Nebraska; and Sioux Falls, South Dakota forecast offices), the Iowa Department of Natural Resources, the Iowa Department of Transportation, each County Engineer in Iowa, and the City Engineer or other public official in each Iowa community that has a population of 5,000 or more. Also, because some counties and municipalities hire consultants to manage their engineering requirements, the survey was sent to the Consulting Engineers Council of Iowa in Des Moines, Iowa, with the request that its management forward copies of the survey to Council members who fulfill the functions of a county or municipal engineer. Survey recipients were asked to forward copies of the survey to other agencies that use streamflow data but might not receive the survey, or to request that the USGS send the survey to such agencies. Several additional forms were mailed in response to these requests. In all, about 210 forms were sent.

\section{SURVEY RESPONSES}

A total of 181 forms were returned with 112 of the respondents indicating that they use USGS streamflow data for at least one of the categories shown on the survey. Many respondents made comments about the stream-gaging network. Several respondents requested information concerning available streamflow data and several other respondents requested information about installing stream-gaging stations.

All of the streamflow-data-use categories shown on the survey were not mutually exclusive; that is, more than one category might have been specified for what essentially is a single use of streamflow data. The responses were not screened, however, to determine whether multiple categories were specified for a single use of streamflow data.

The survey responses are presented at the end of this report in four tables. The same information is presented in tables $1-4$ with the only difference among them being the criterion used to sort the stations. The number of respondents indicating that they use streamflow data for a particular purpose is listed under each category for each station. Response summaries-the number of respondents that use a station's data, the number of categories that were indicated at least once, and the sum of the categories indicated-are also listed for each station.

In table 1, the stations are listed by county in the same order presented in the station list that was included with the survey.

In table 2, the stations are listed in decreasing order by the number of survey respondents indicating that they use the station's data. The largest number of respondents using a single station's data was 13 , which was for data from gaging station 05451500 Iowa River at Marshalltown. The median of the number of respondents per station was 6 and the minimum was 2 . A histogram of the number of respondents per station is shown in figure 2 .

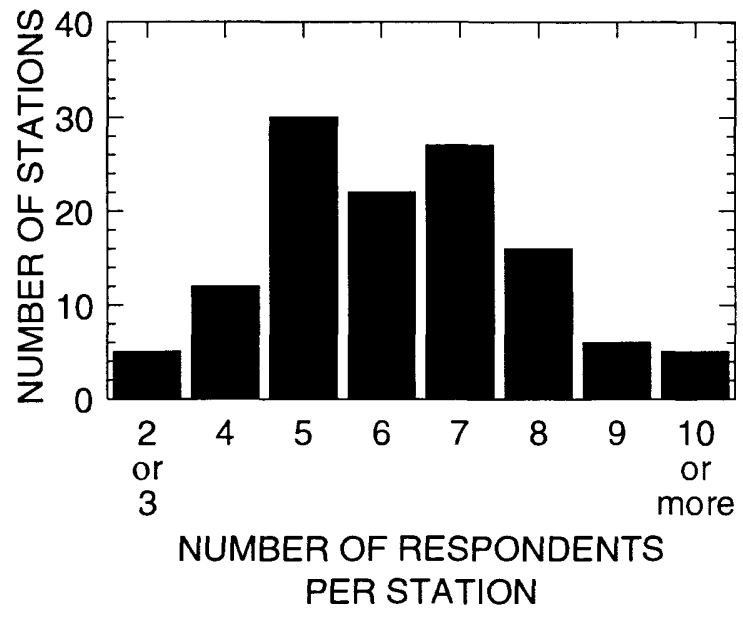

Figure 2. Histogram of number of respondents per station that use streamflow data, lowa USGS stream-gaging network survey (table 2).

In table 3, the stations are listed in decreasing order by the number of data-use categories that were indicated at least once. Eleven categories were indicated for four stations. The median of the number of categories indicated was 9 and the minimum was 5 . A histogram of the number of categories indicated per station is shown in figure 3 . 


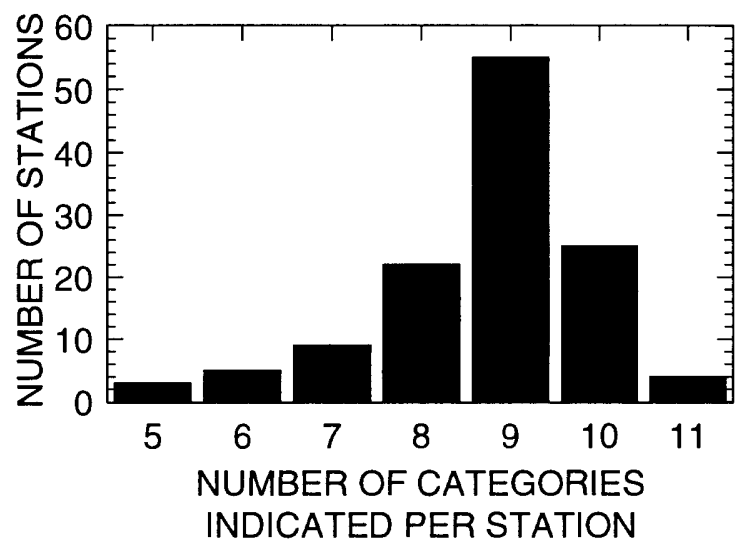

Figure 3. Histogram of number of streamflow-datause categories indicated per station, lowa USGS stream-gaging network survey (table 3 ).

In table 4, the stations are listed in decreasing order by the sum of the categories indicated by the respondents. The largest sum of the categories indicated was 50, which was for gaging station 05451500 Iowa River at Marshalltown. The median of the sum of the categories indicated was 19 and the minimum was 7. A histogram of the sum of the categories indicated is shown in figure 4 .

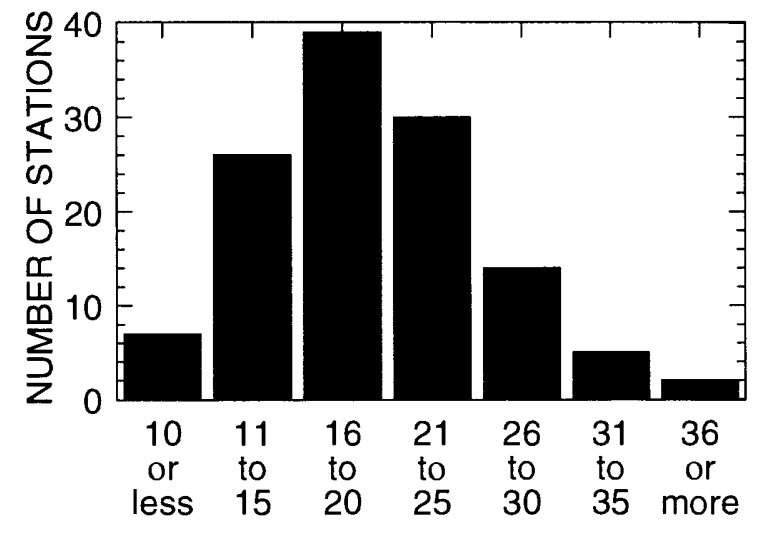

\section{SUM OF CATEGORIES INDICATED PER STATION}

Figure 4. Histogram of sum of streamflow-data-use categories indicated per station, lowa USGS stream-gaging network survey (table 4).

\section{SUMMARY}

A survey was sent to over 200 Federal, State, and local agencies that might use streamflow data collected by the U.S. Geological Survey in Iowa. A total of 181 forms were returned and 112 agencies indicated that they use streamflow data. The responses show that streamflow data from the Iowa USGS stream-gaging network, which in 1996 is composed of 117 stations, are used by many agencies for many purposes and that many stations provide streamflow data that fulfill a variety of joint purposes. The median value of the number of respondents per station that use data from the station was 6 and the median value of the number of data-use categories indicated per station was 9 . The comments of some survey respondents suggest that not all agencies that might use streamflow data are aware of the Iowa USGS stream-gaging network.

The results of this survey can be used by agencies that fund the Iowa USGS stream-gaging network to help them decide which stations to continue to support if it becomes necessary to reduce the size of the network. As demands on the State's water resources increase, having a network that satisfies as many joint purposes as possible becomes increasingly important.

\section{REFERENCES}

Burmeister, I.L., and Lara, O.G., 1984, Cost-effectiveness of the stream-gaging program in Iowa: U.S. Geological Survey Water-Resources Investigations Report 844171, $68 \mathrm{p}$.

May, J.E., Sneck-Fahrer, D., Gorman, J.G., Goodrich, R.D., Nations, B.K., and Miller, V.E., 1995, Water Resources Data, Iowa, Water Year 1994: U.S. Geological Survey Water-Data Report IA-94-1, 370 p.

Wahl, K.L., and Crippen, J.R., 1984, A pragmatic approach to evaluating a multipurpose stream-gaging network: U.S. Geological Survey Water-Resources Investigations Report 84-4228, 13 p. 


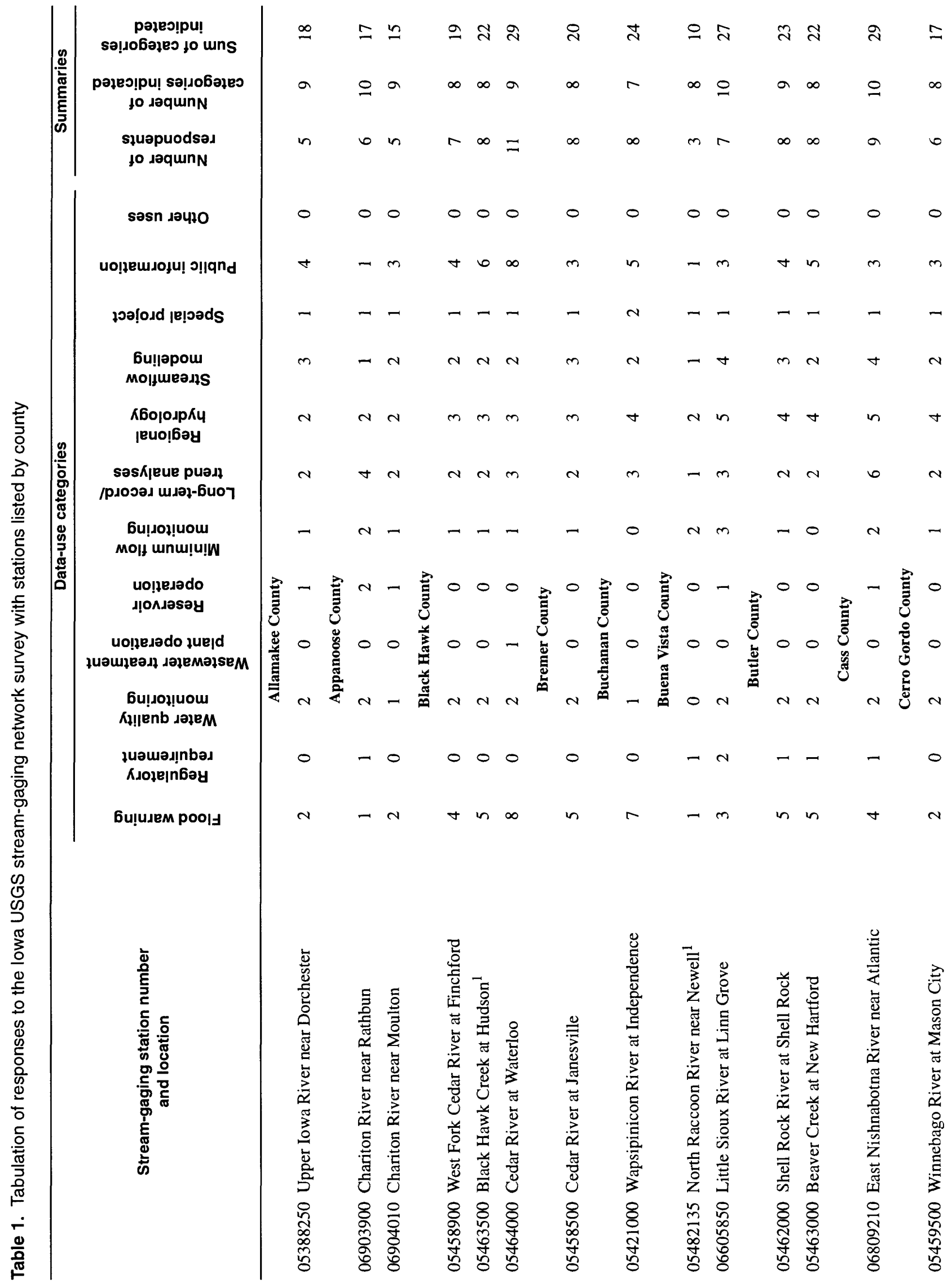




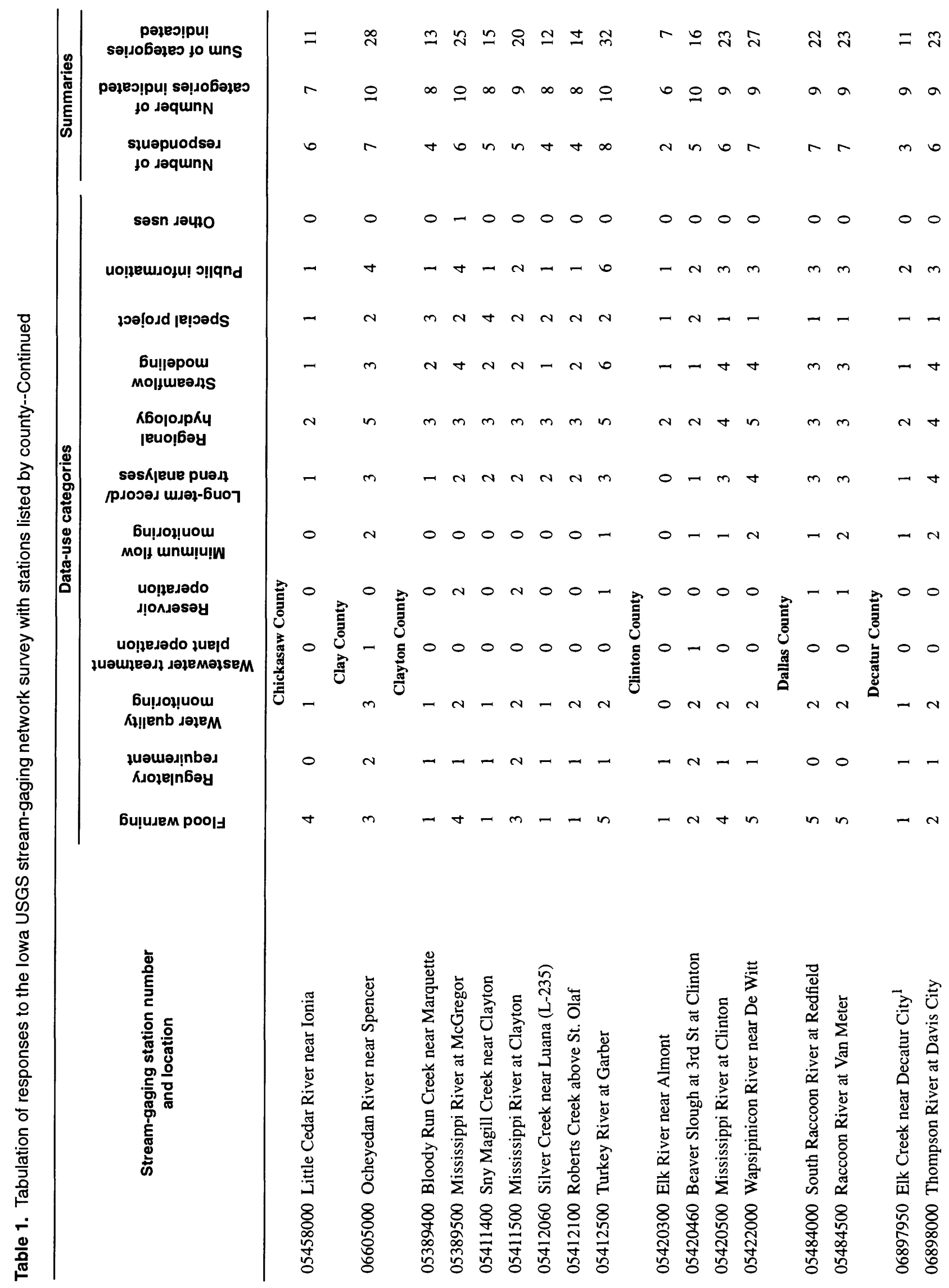




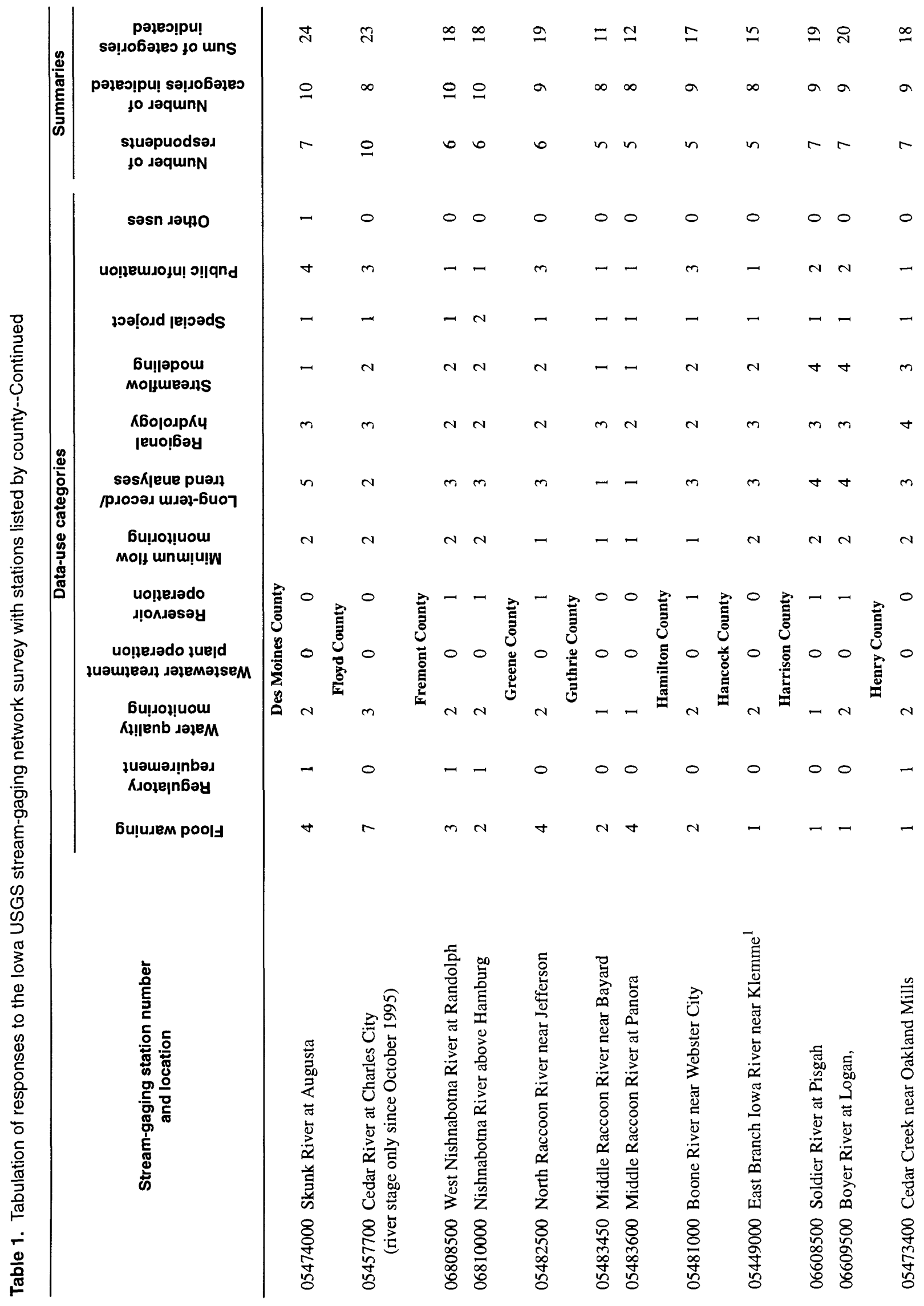




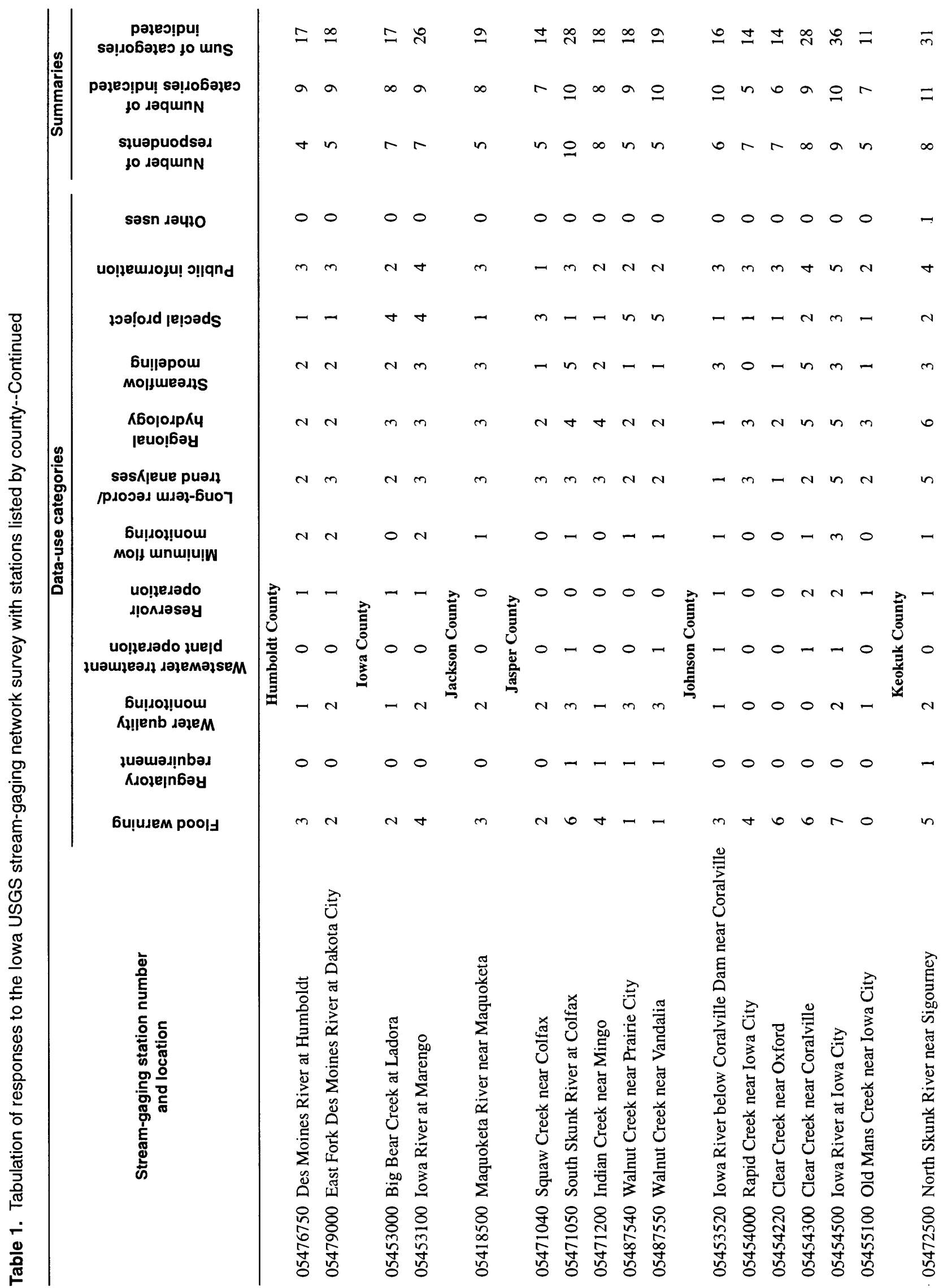




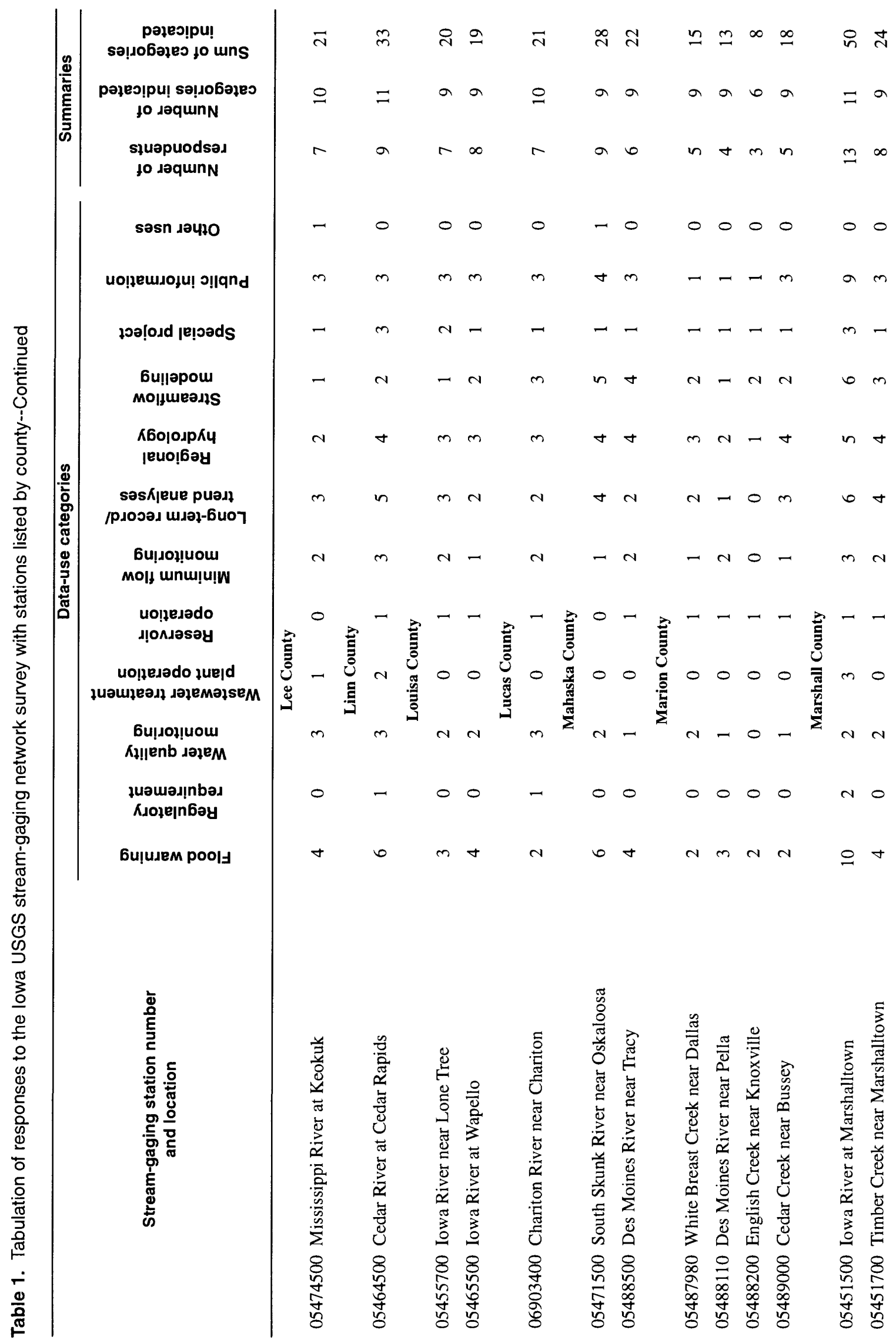




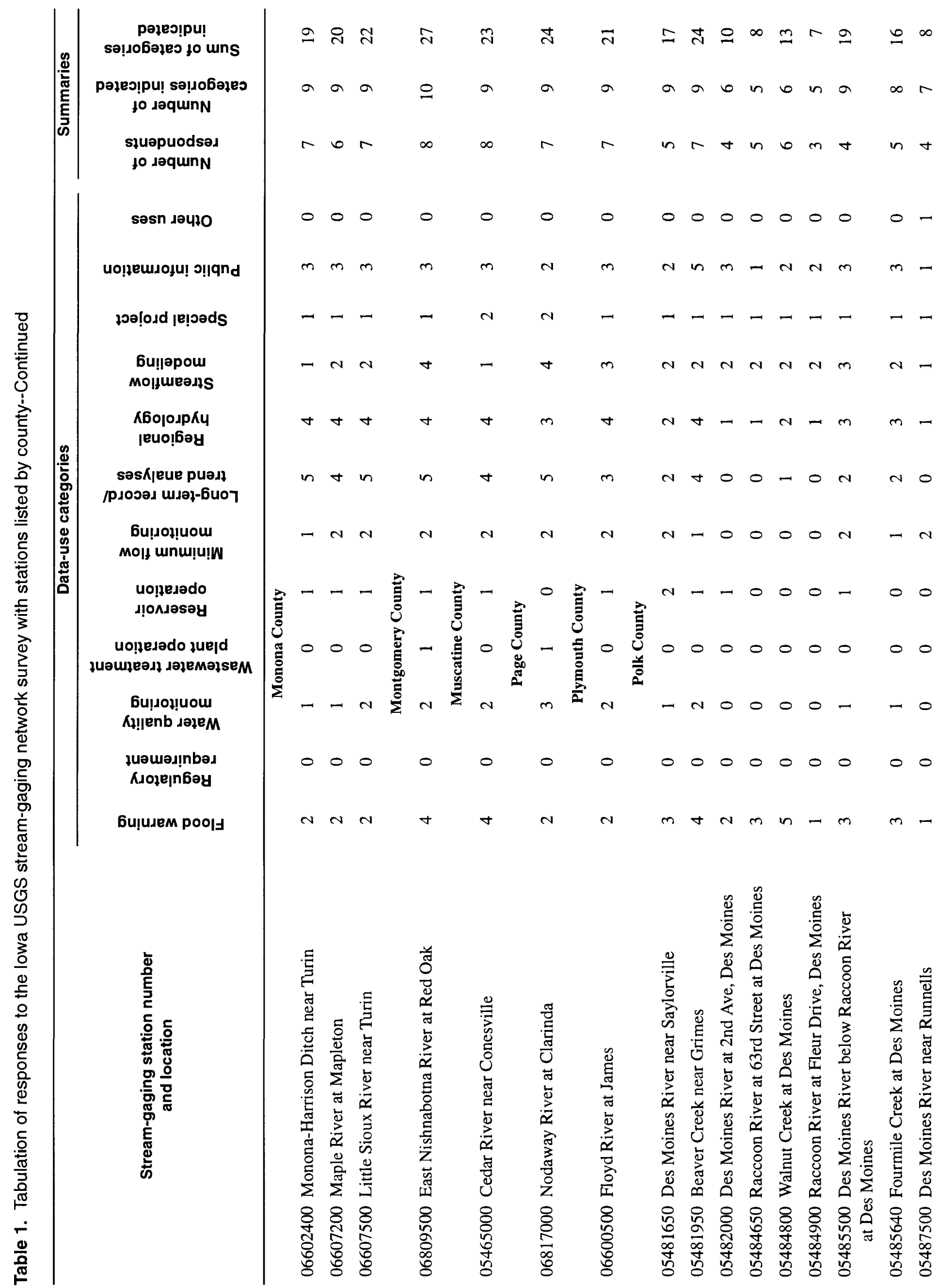




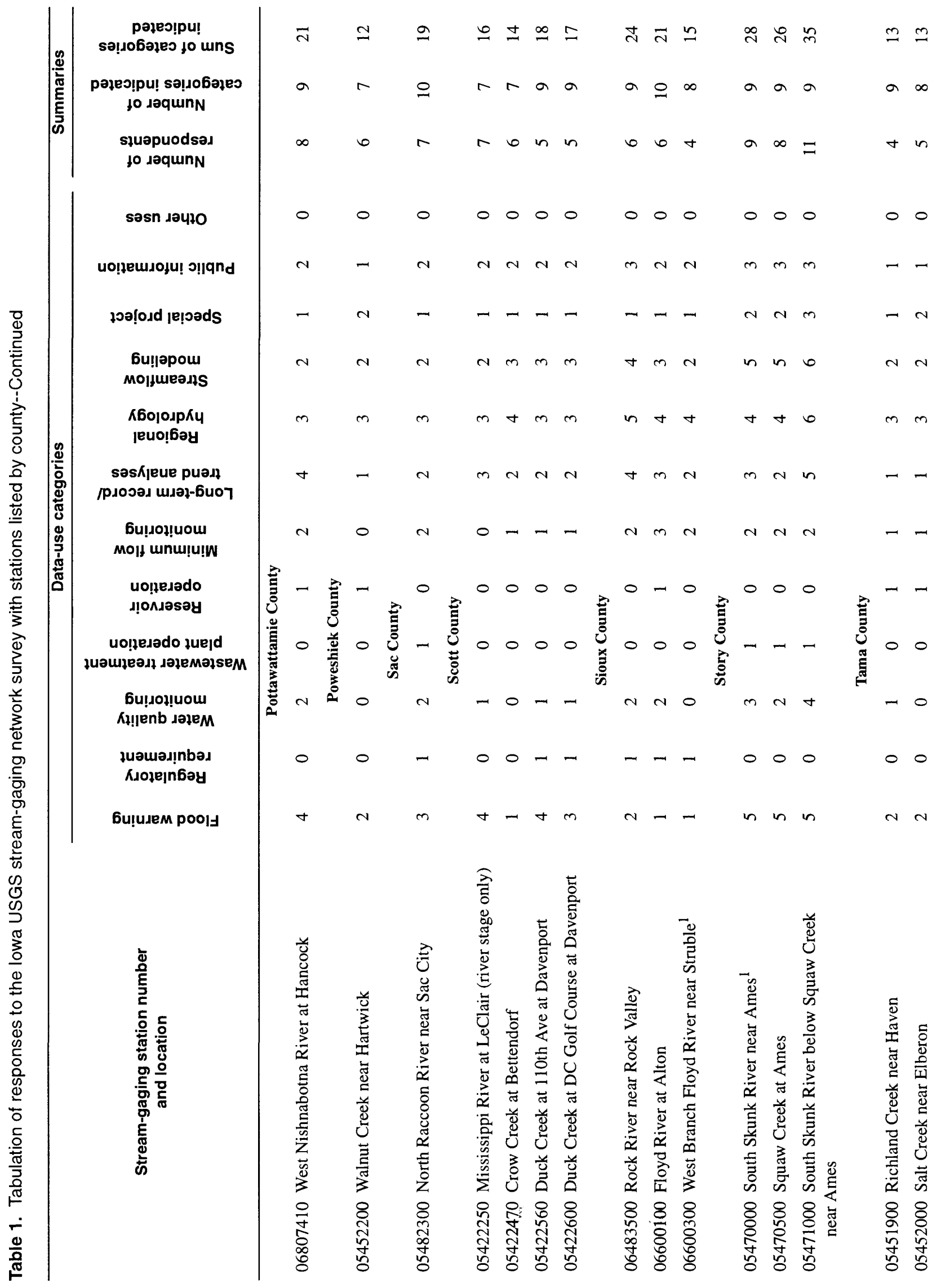




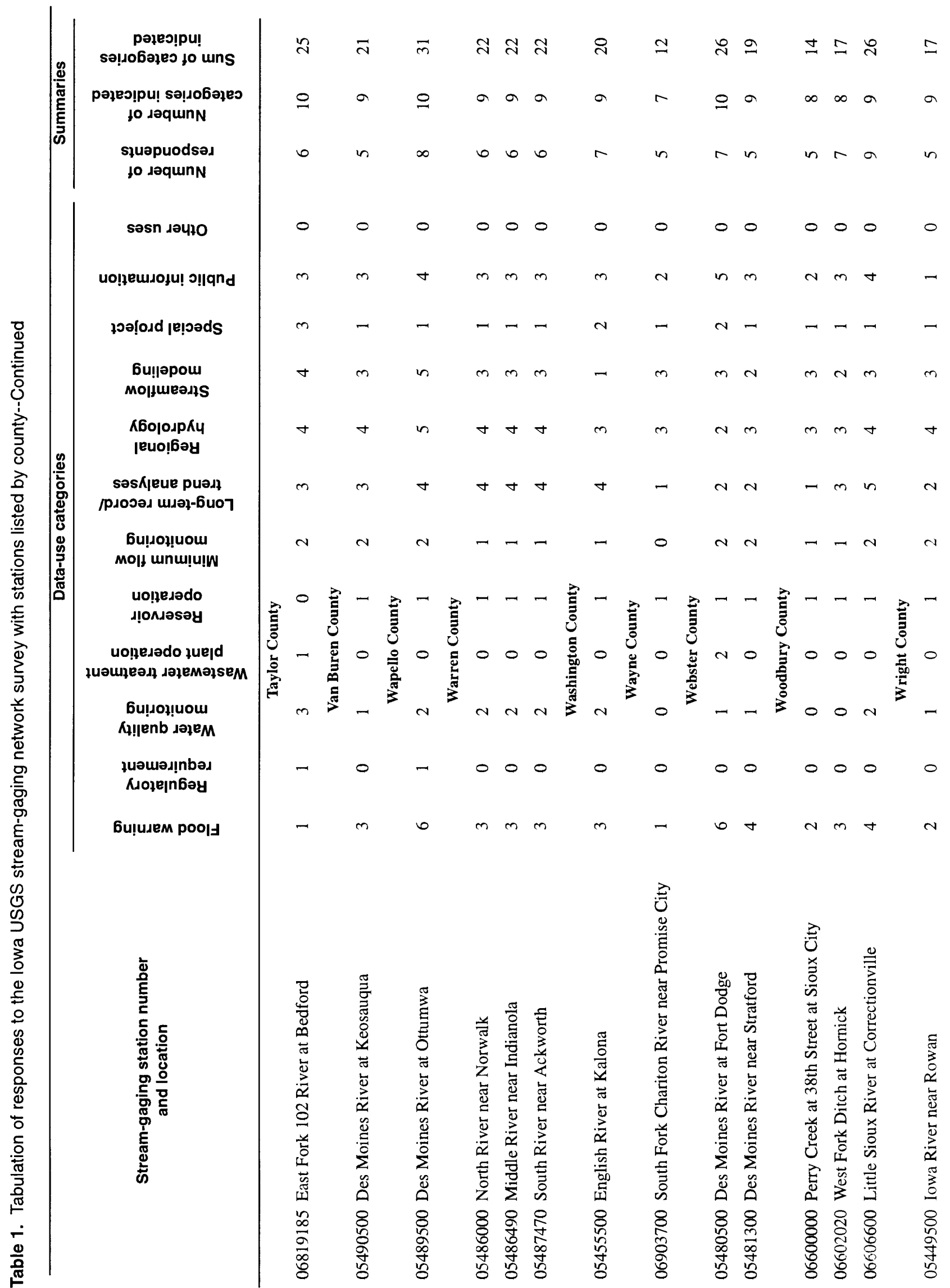




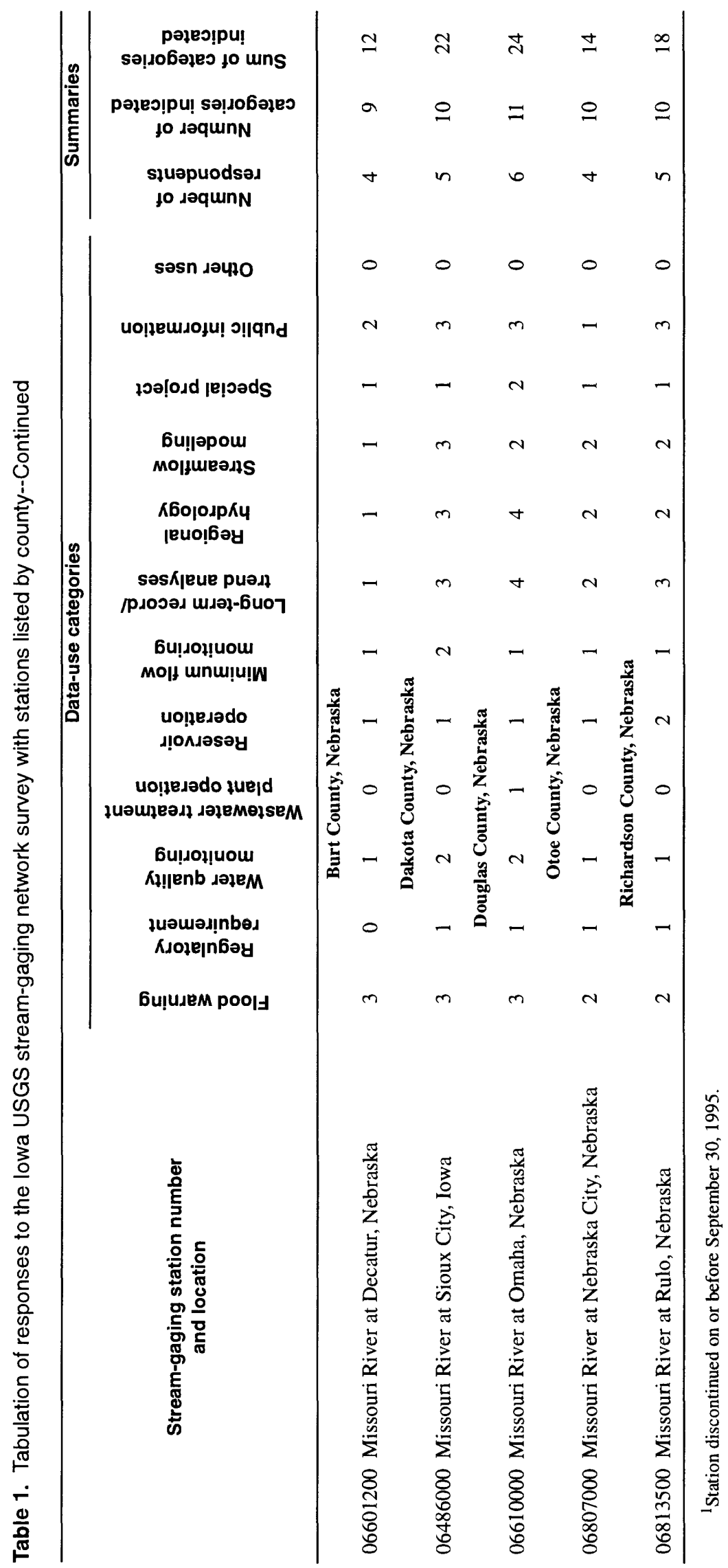




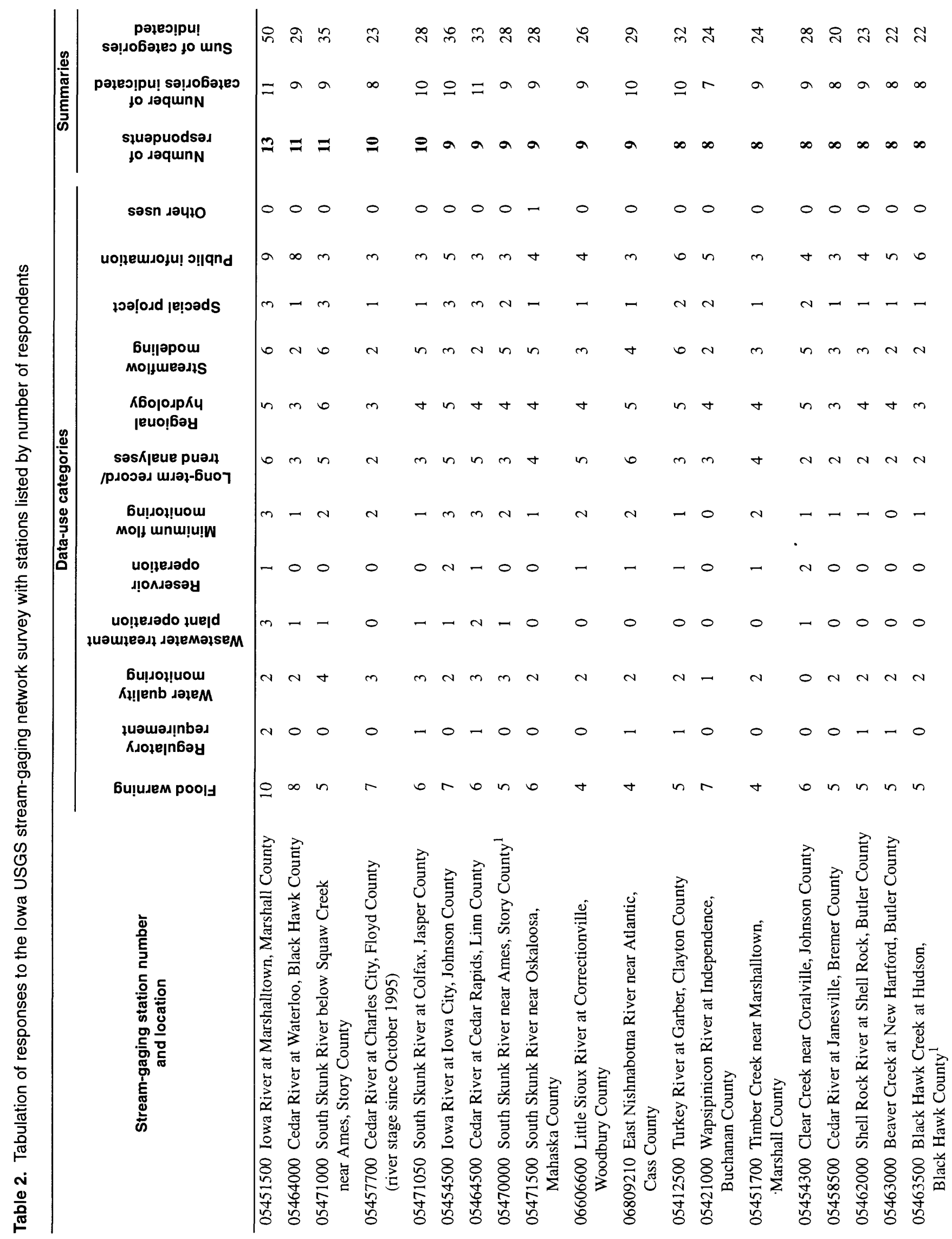




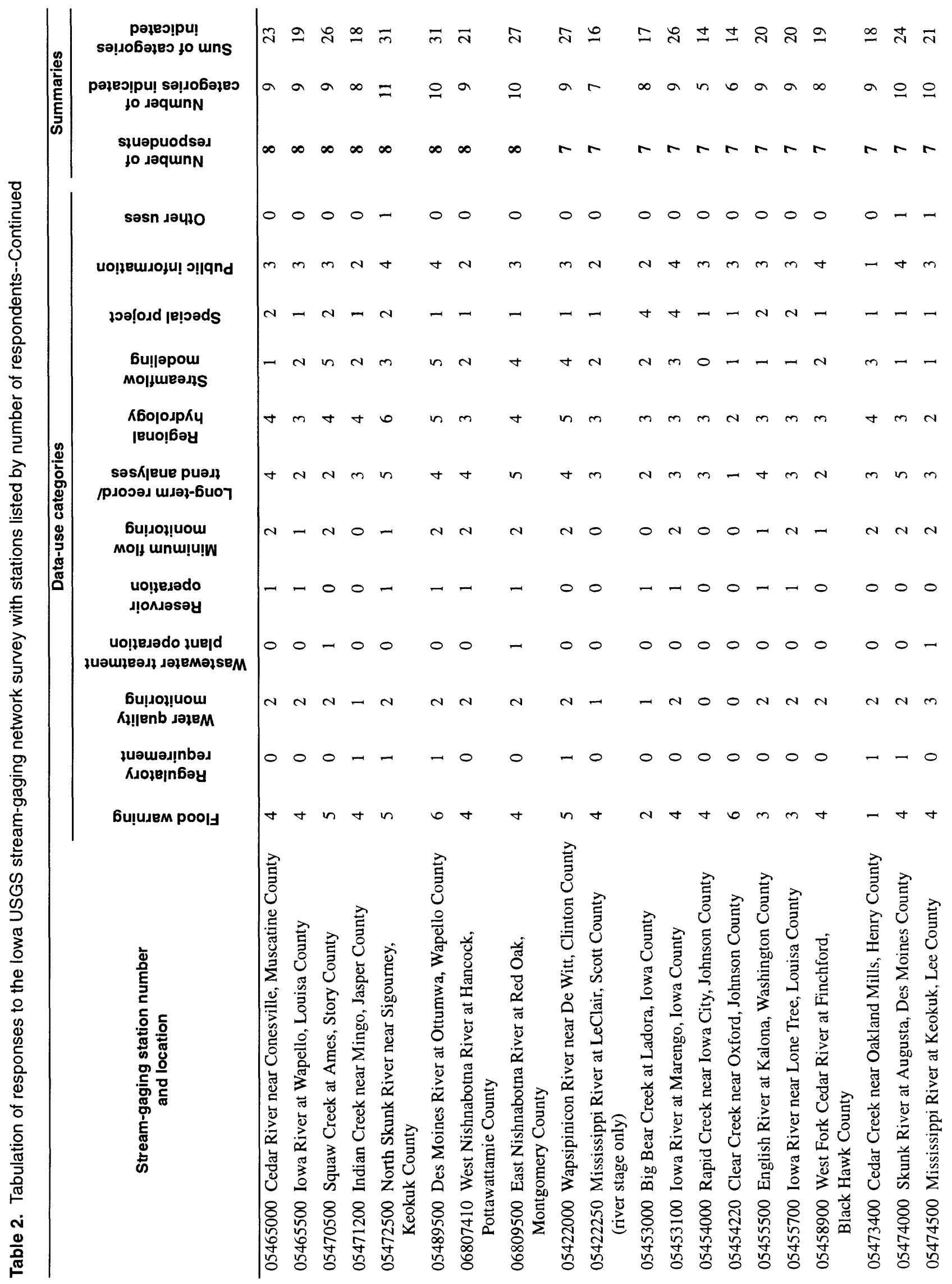




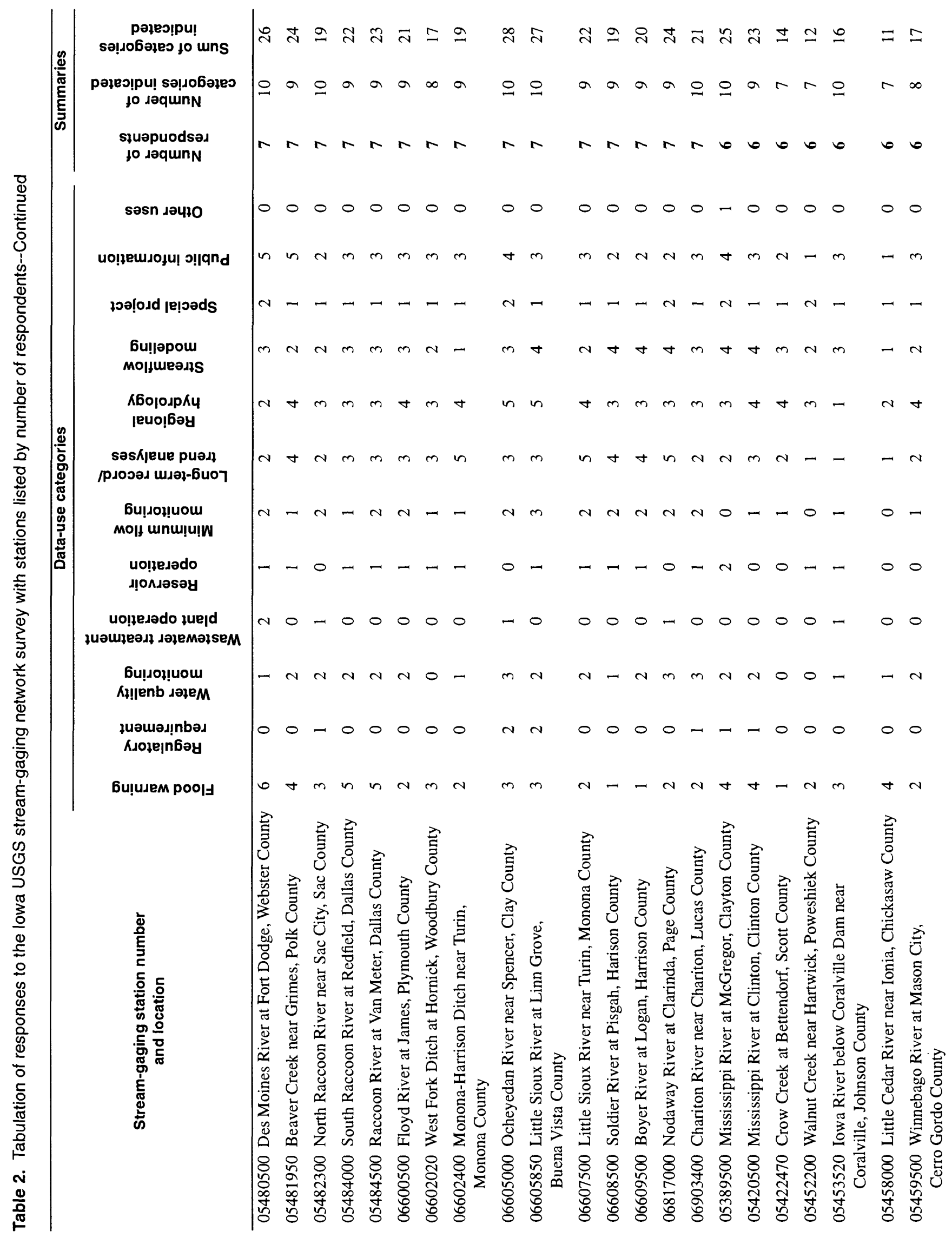




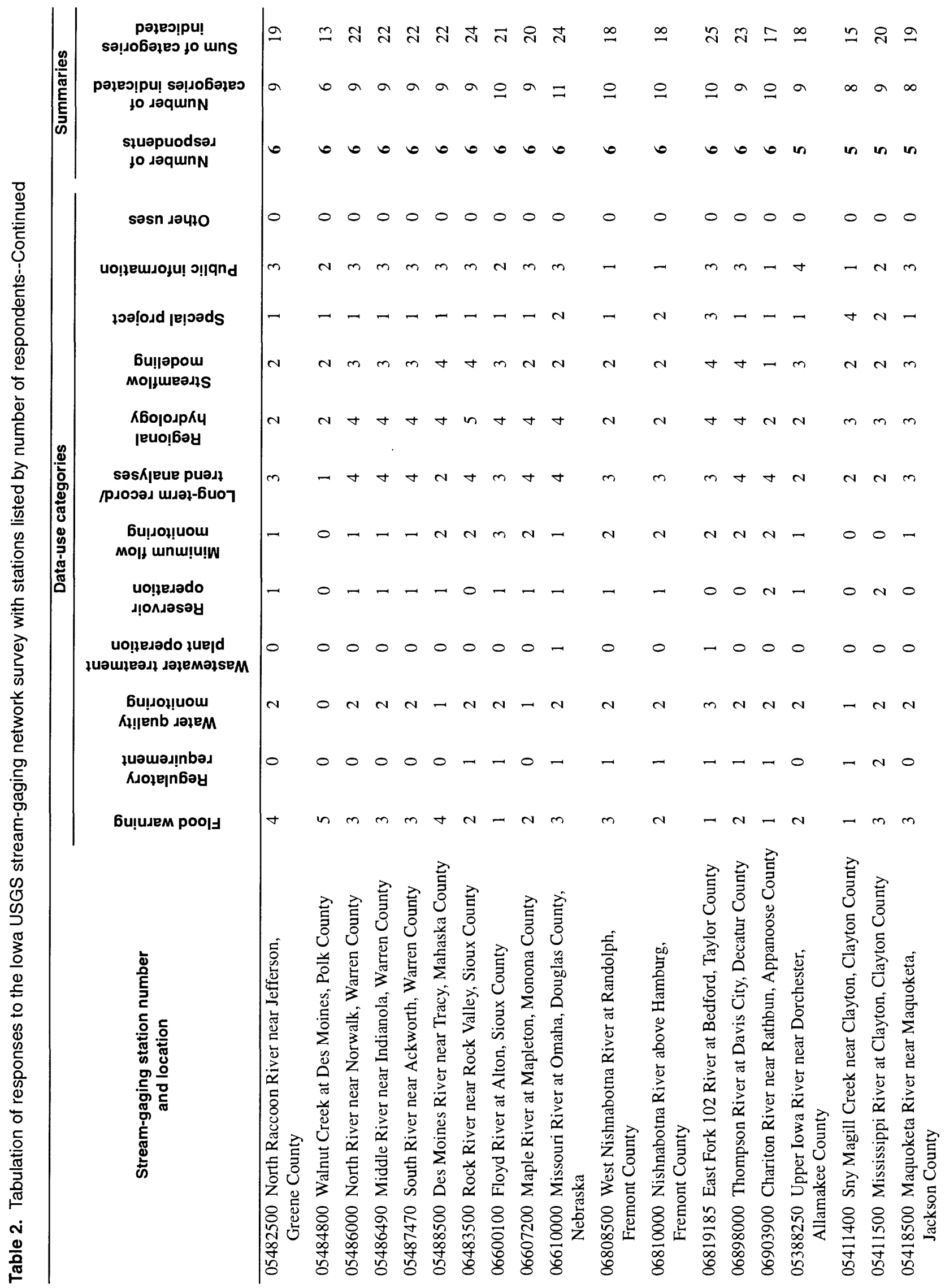




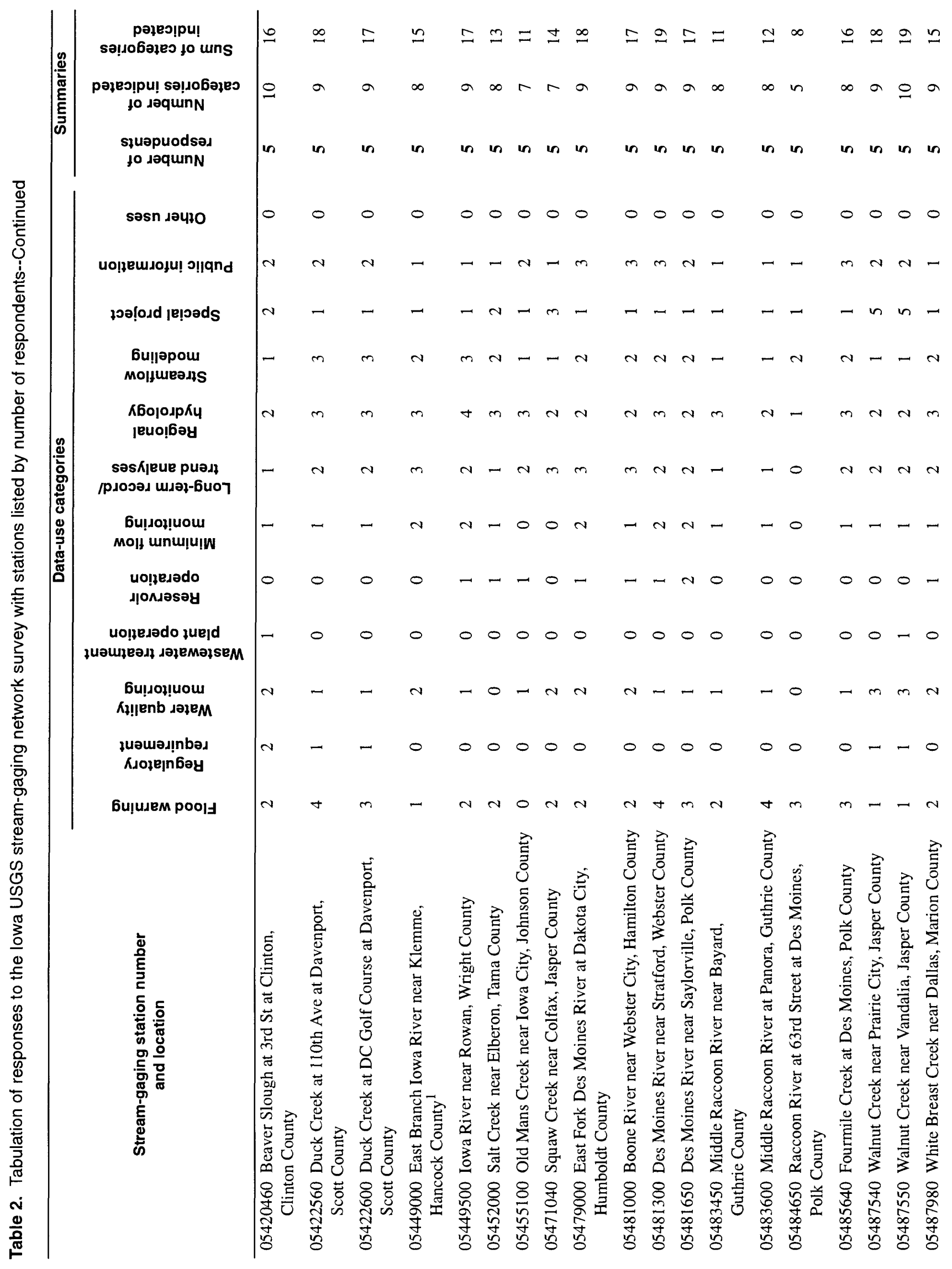




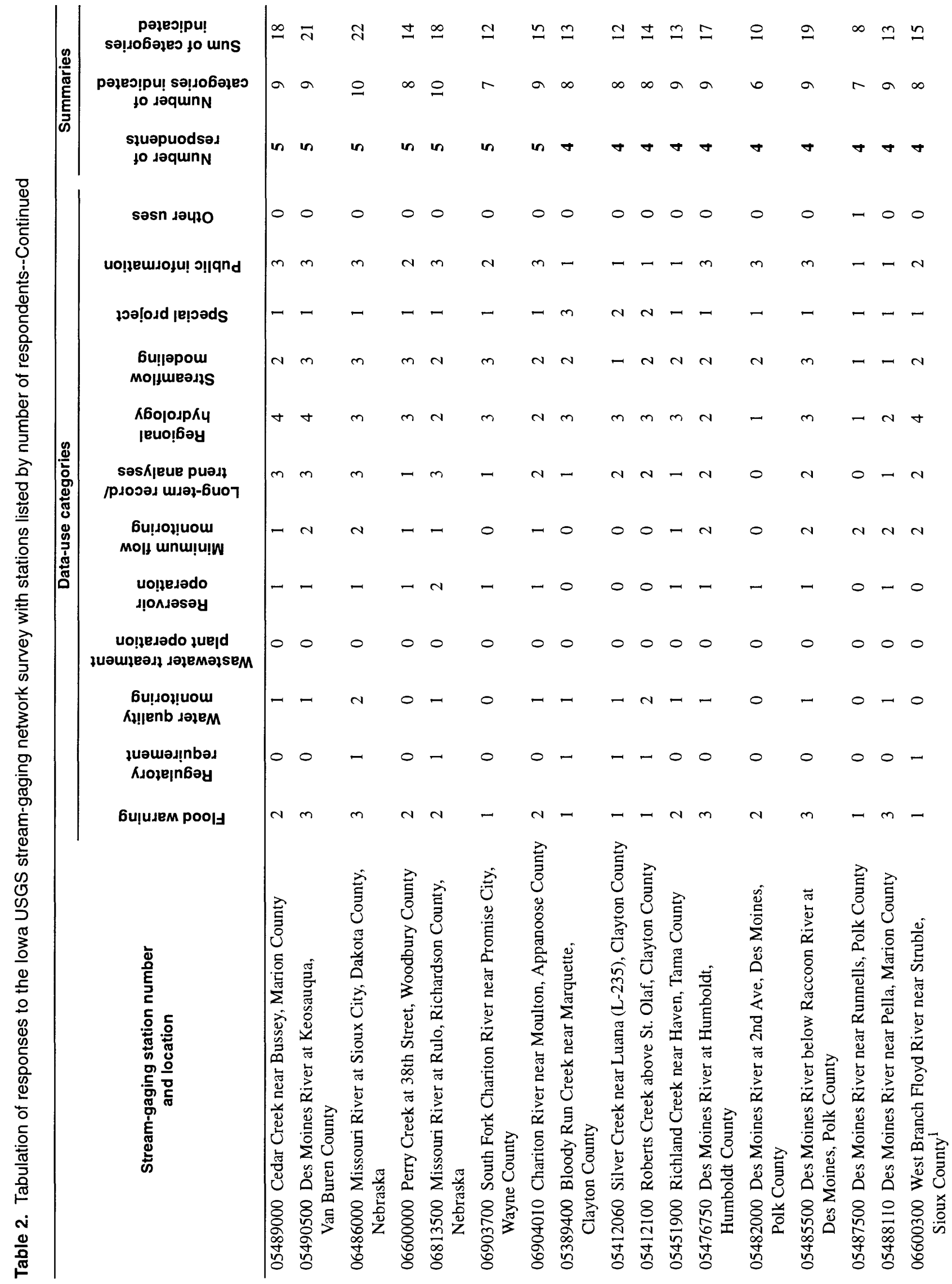




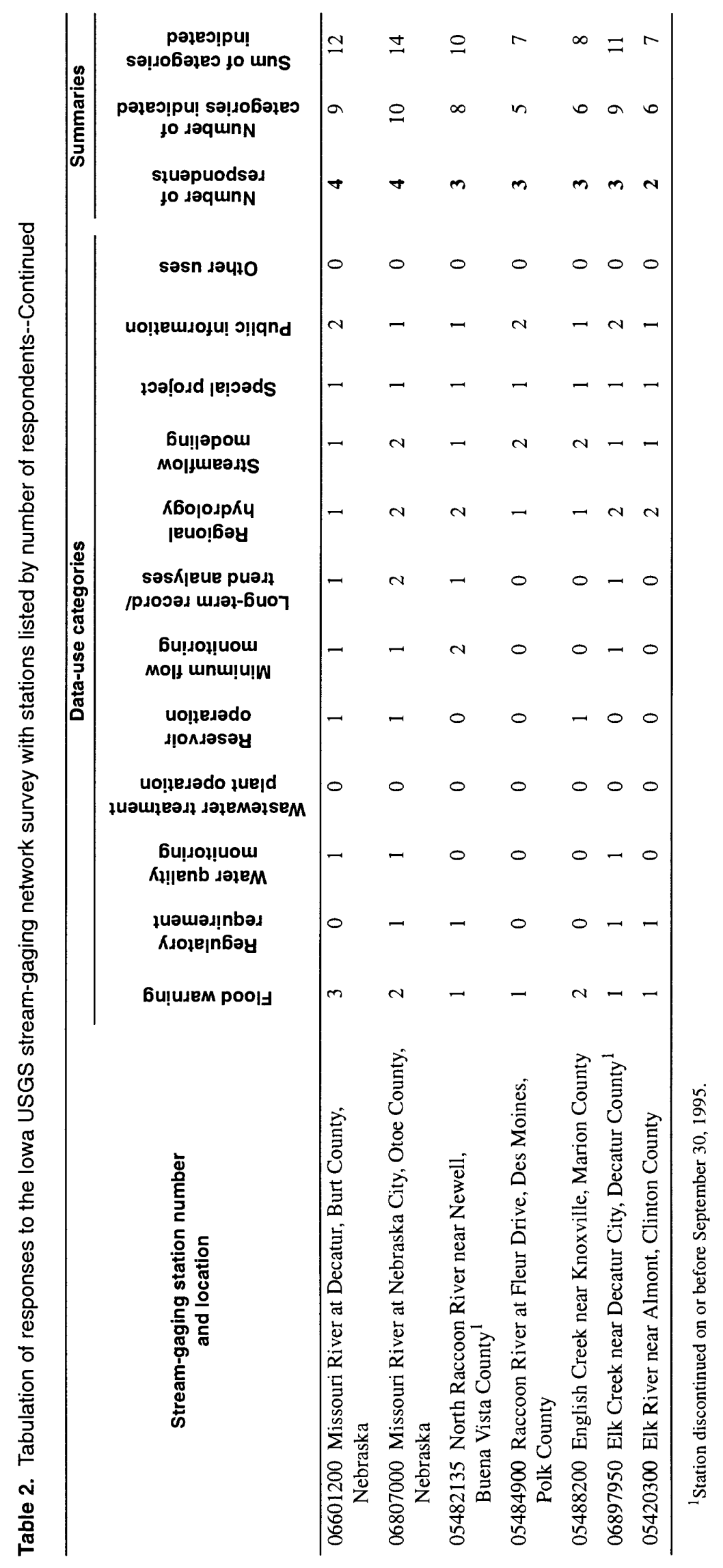




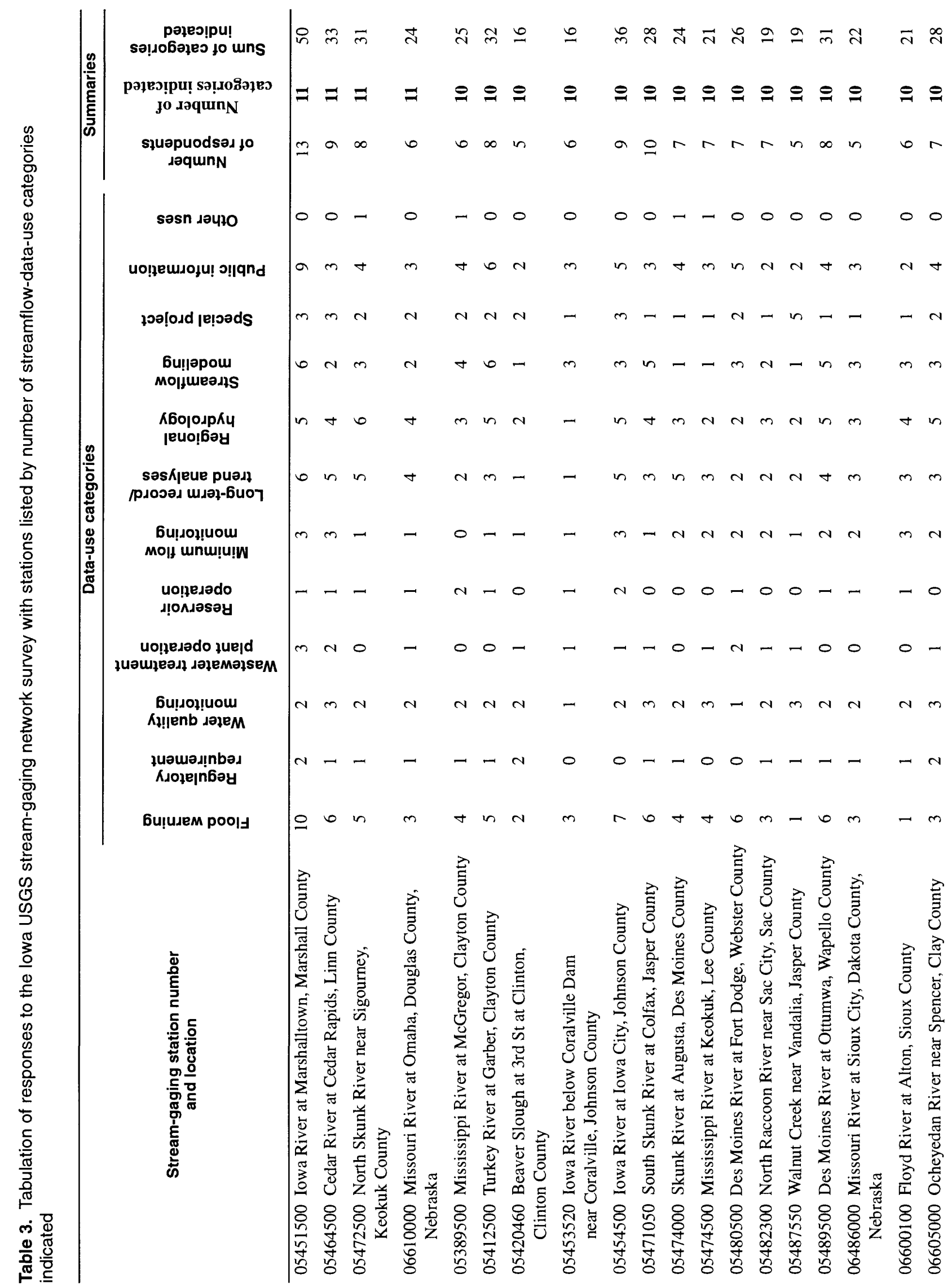




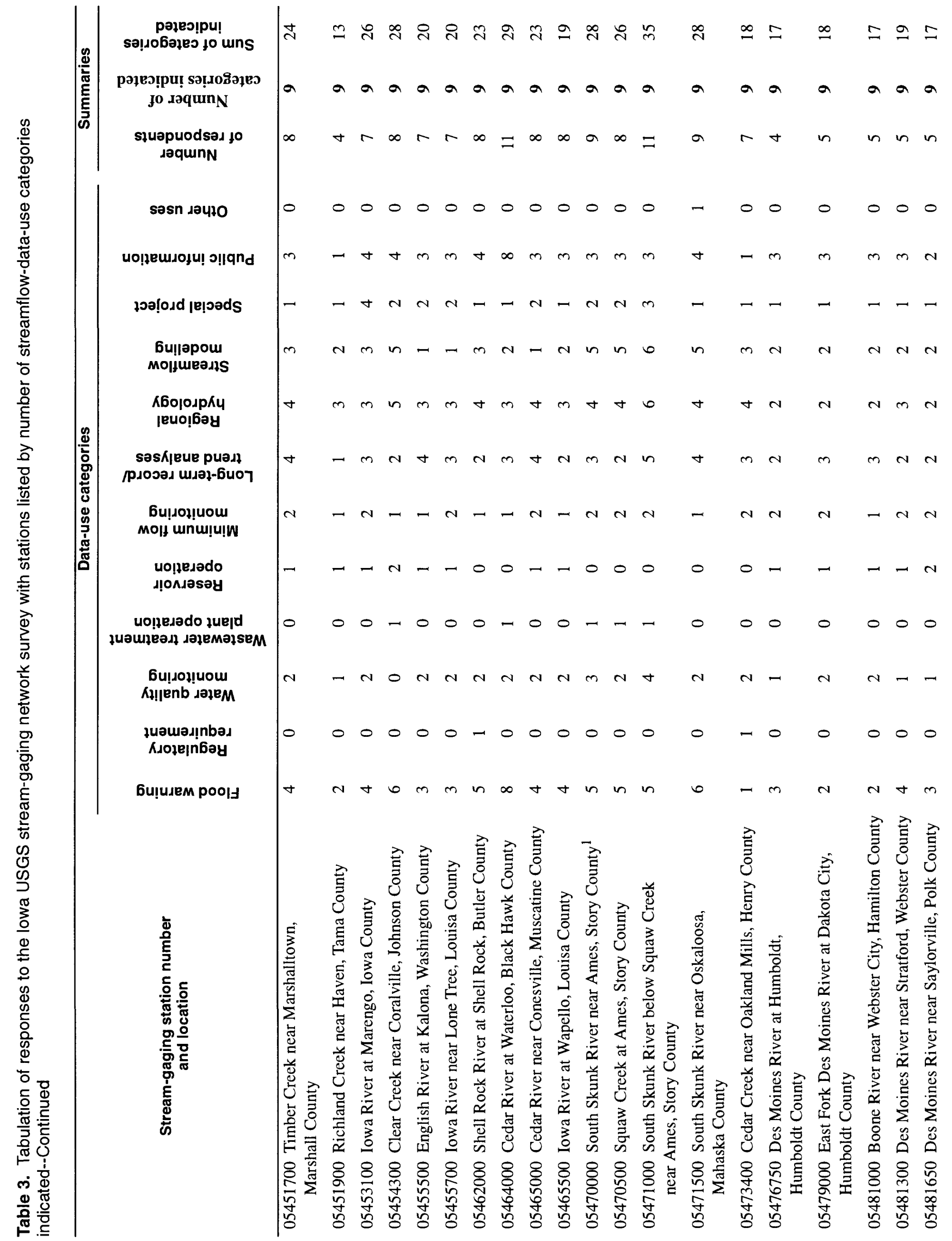




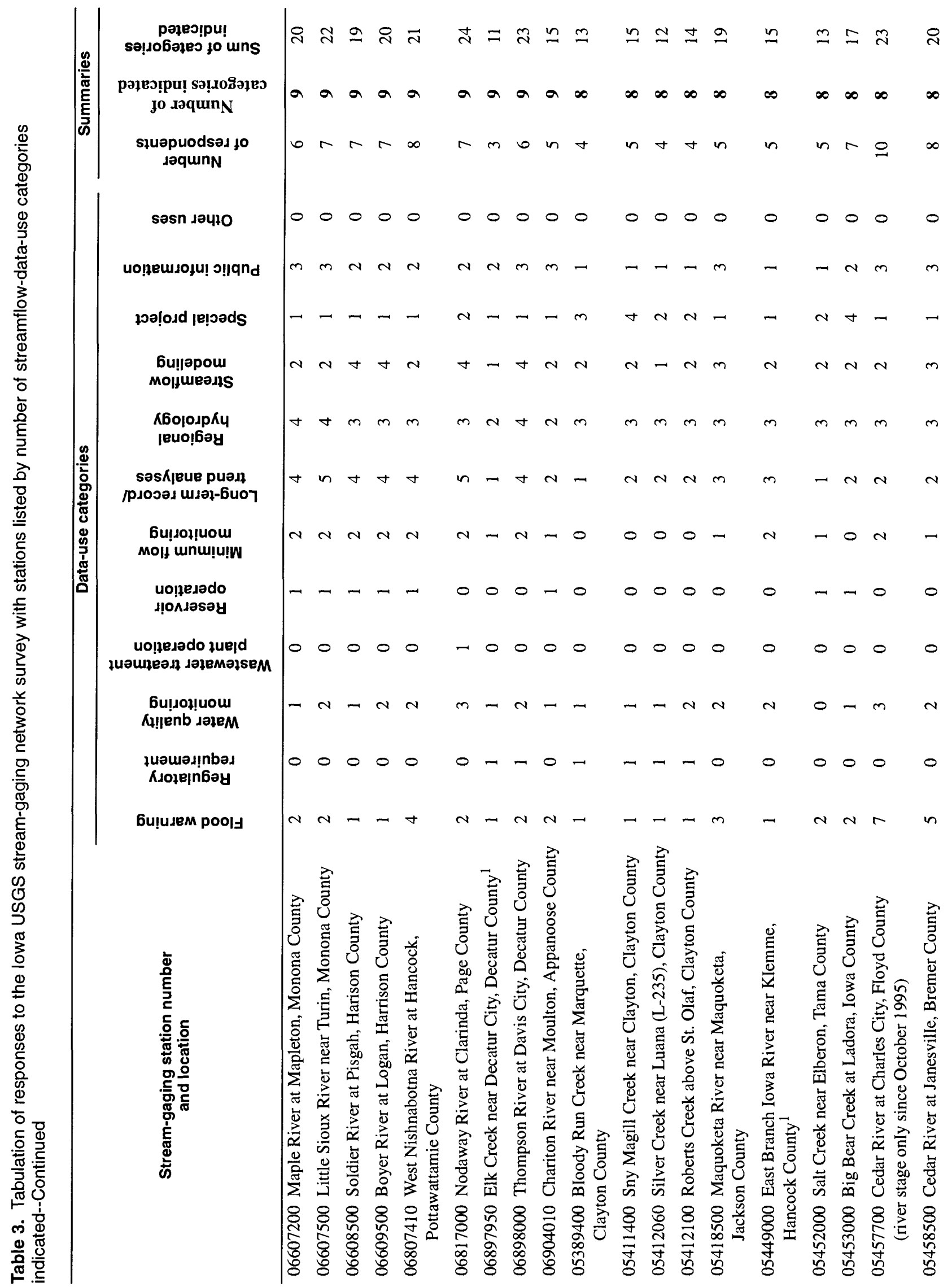




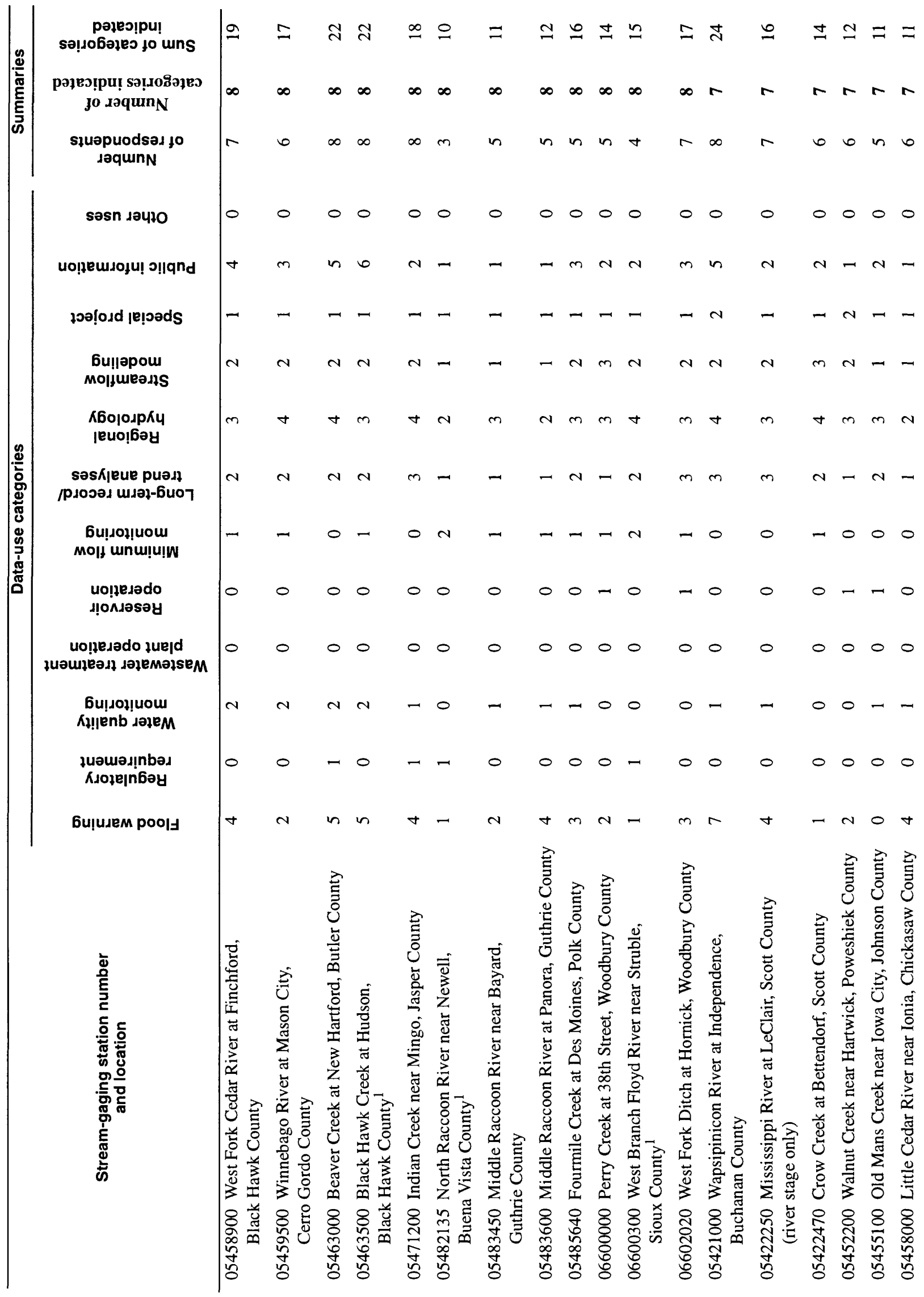




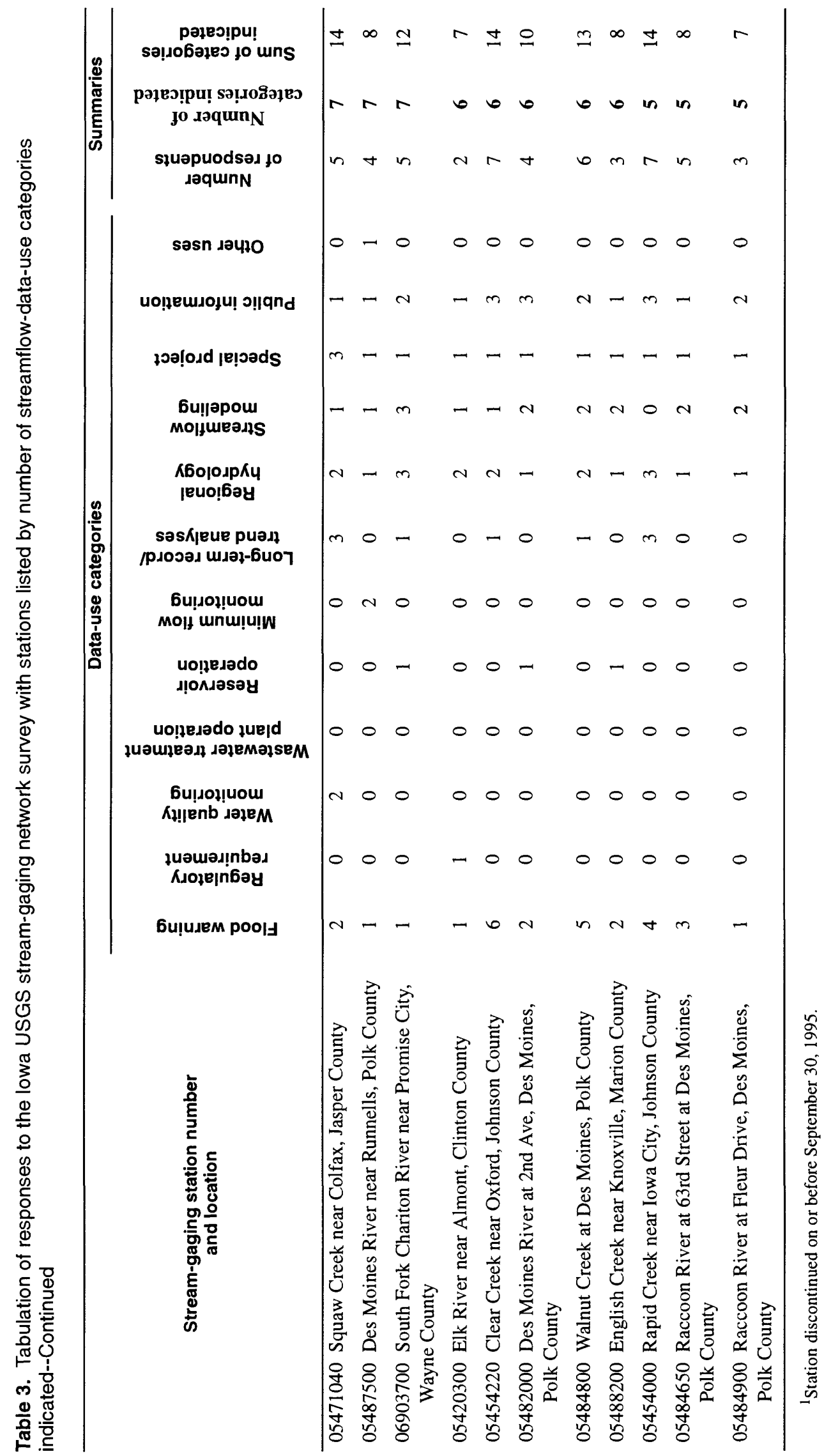




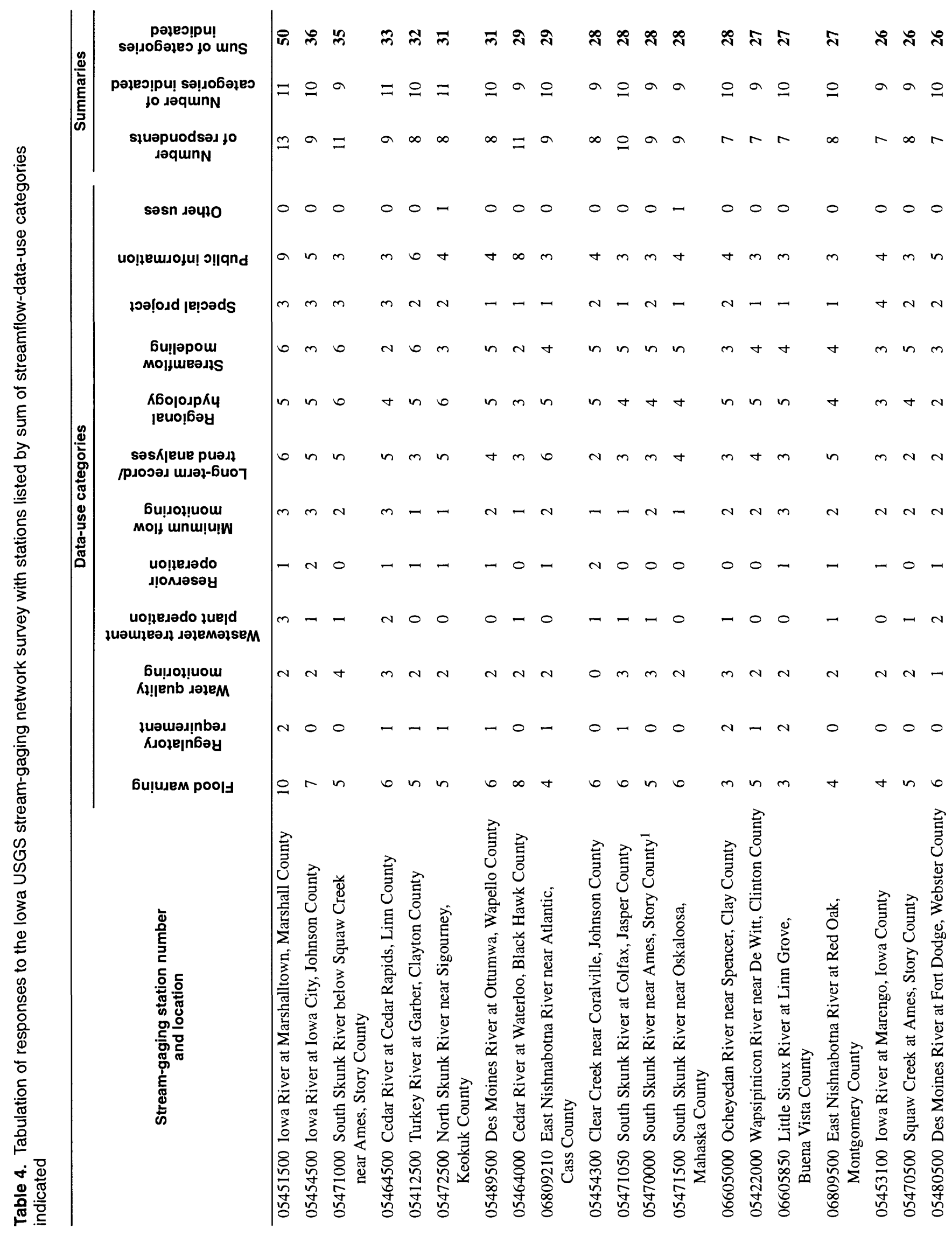




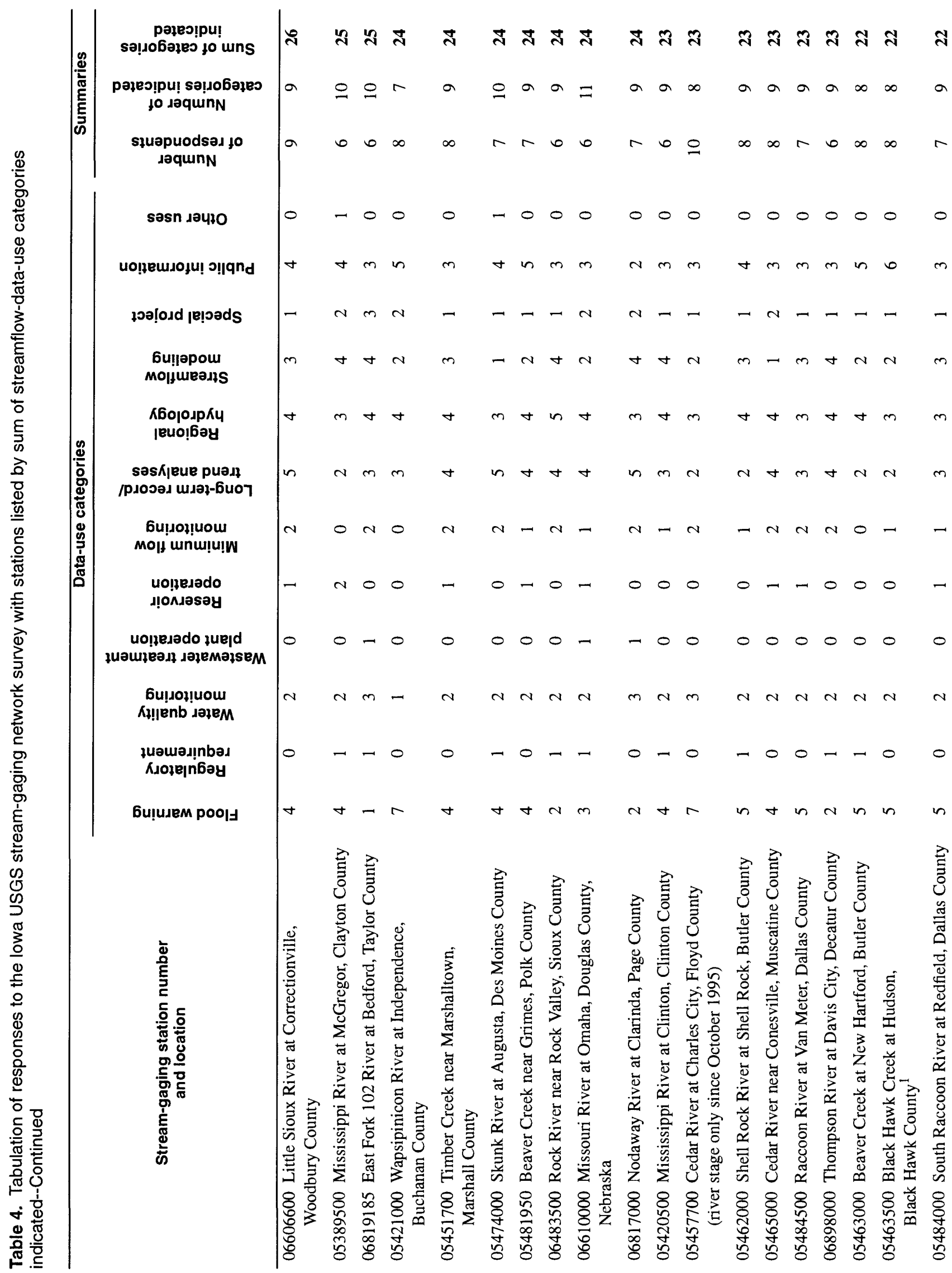




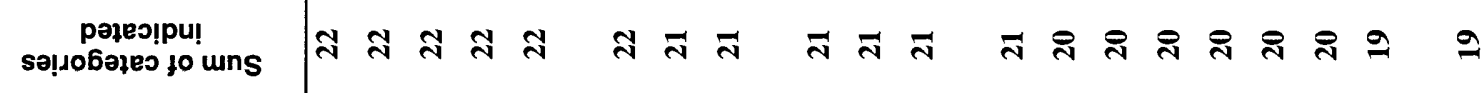

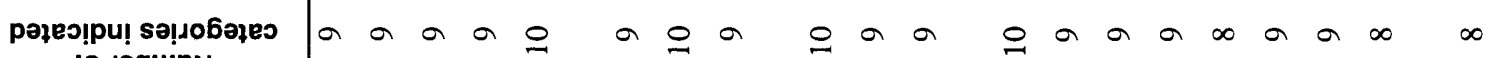
to doqunn

squopuodsad to JəqunN

uọ̣eusoju! ग!|qnd

poo!̣od ןẹpods

6u!ןәpow

Mo|jueədis

КБородpK4

jeuolibay

səsא|eue puəג

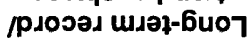

6u!̣oม!uous Mo|f unu!u!w

uo!̣esado

ц!ONJәsəY

uopgesədo que|d

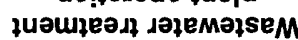

Gu!̣oม! บou ᄉ‼

ในอนอม!nbอม

Ksoze|nбoy

Gu!uem pools
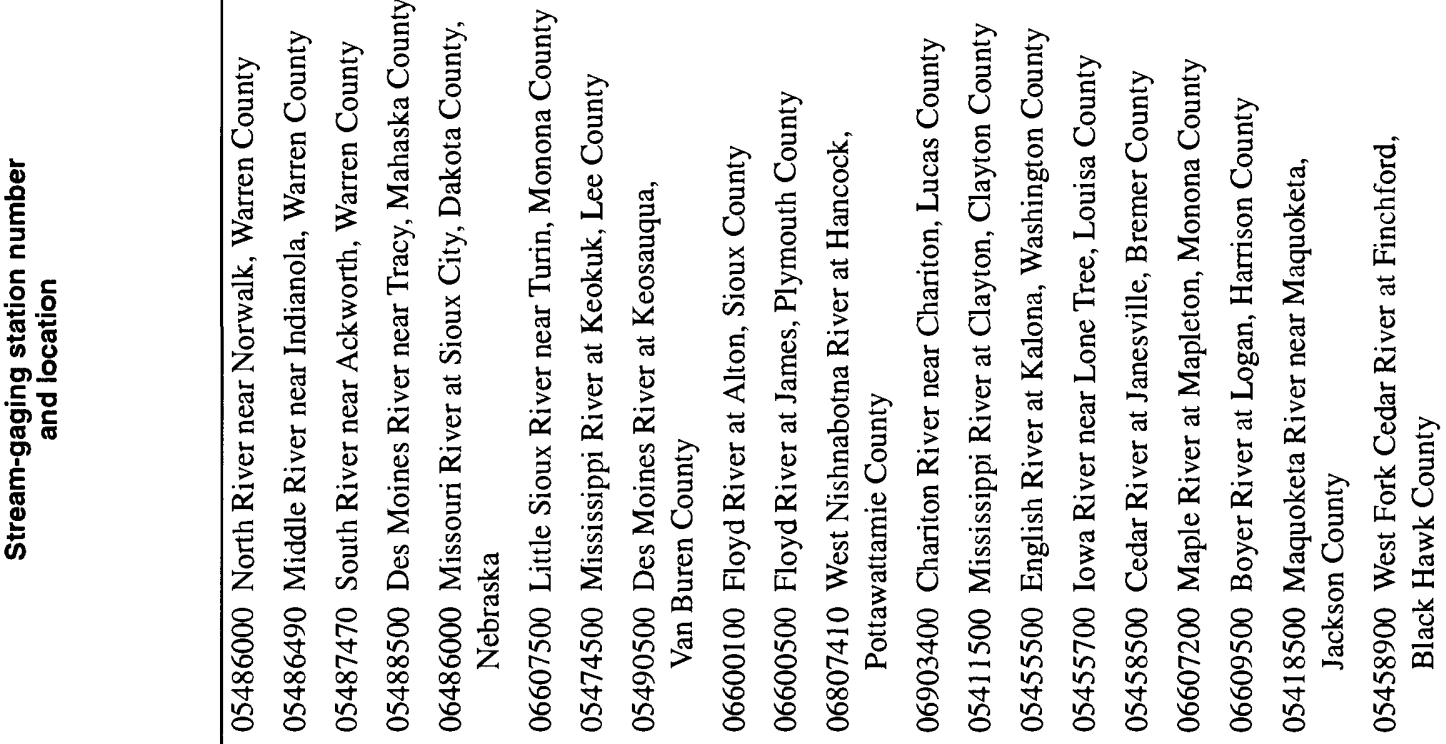


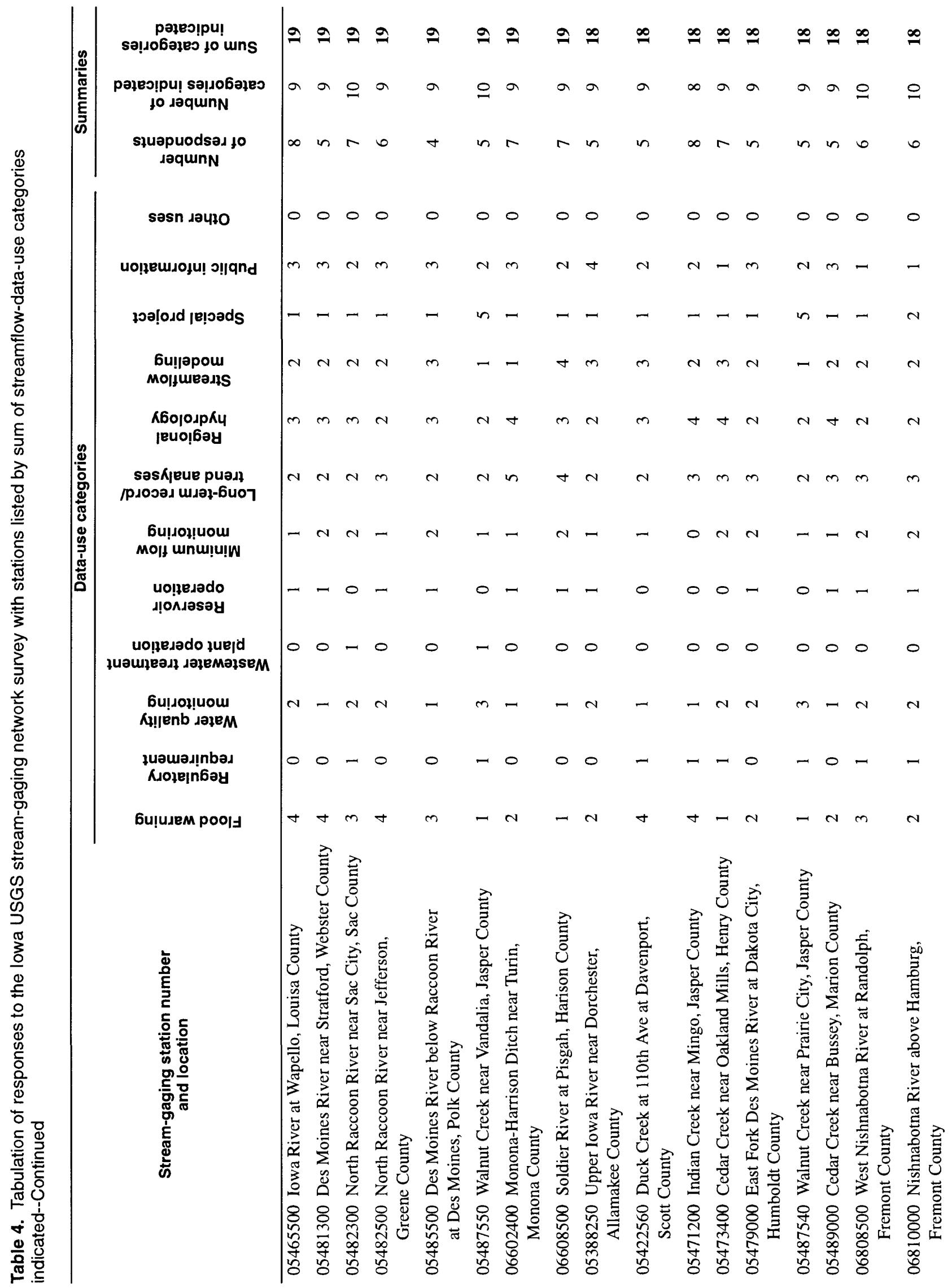




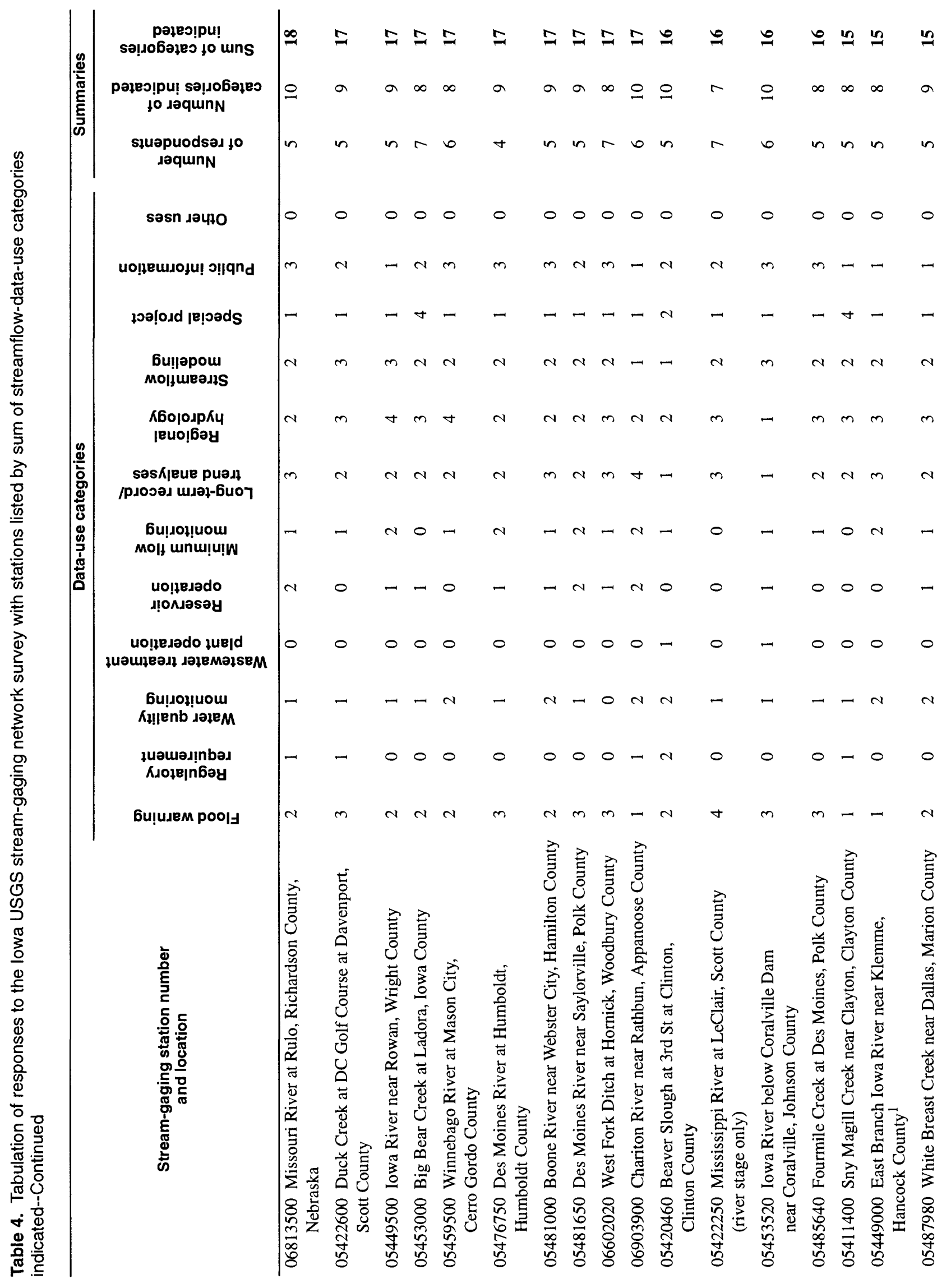




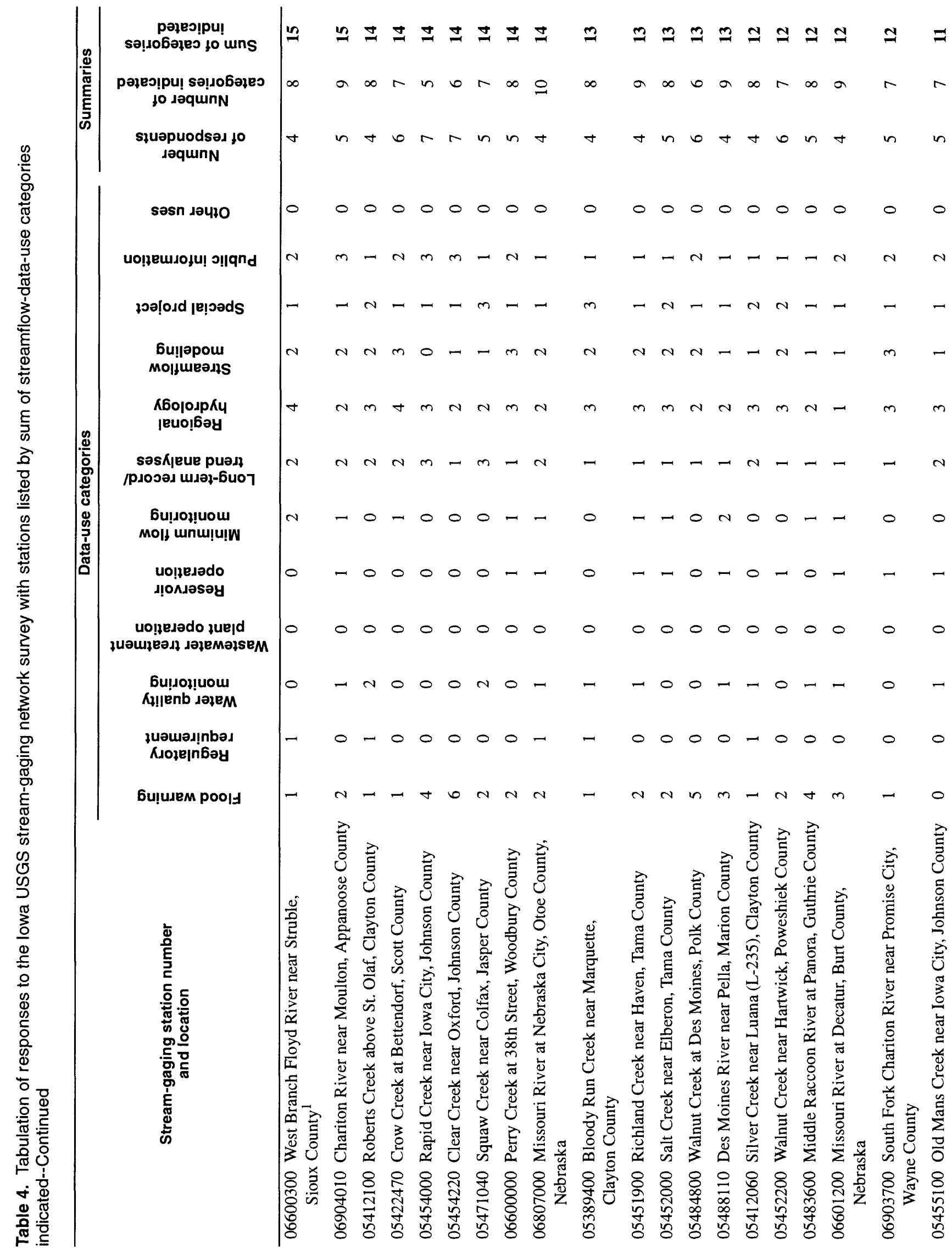




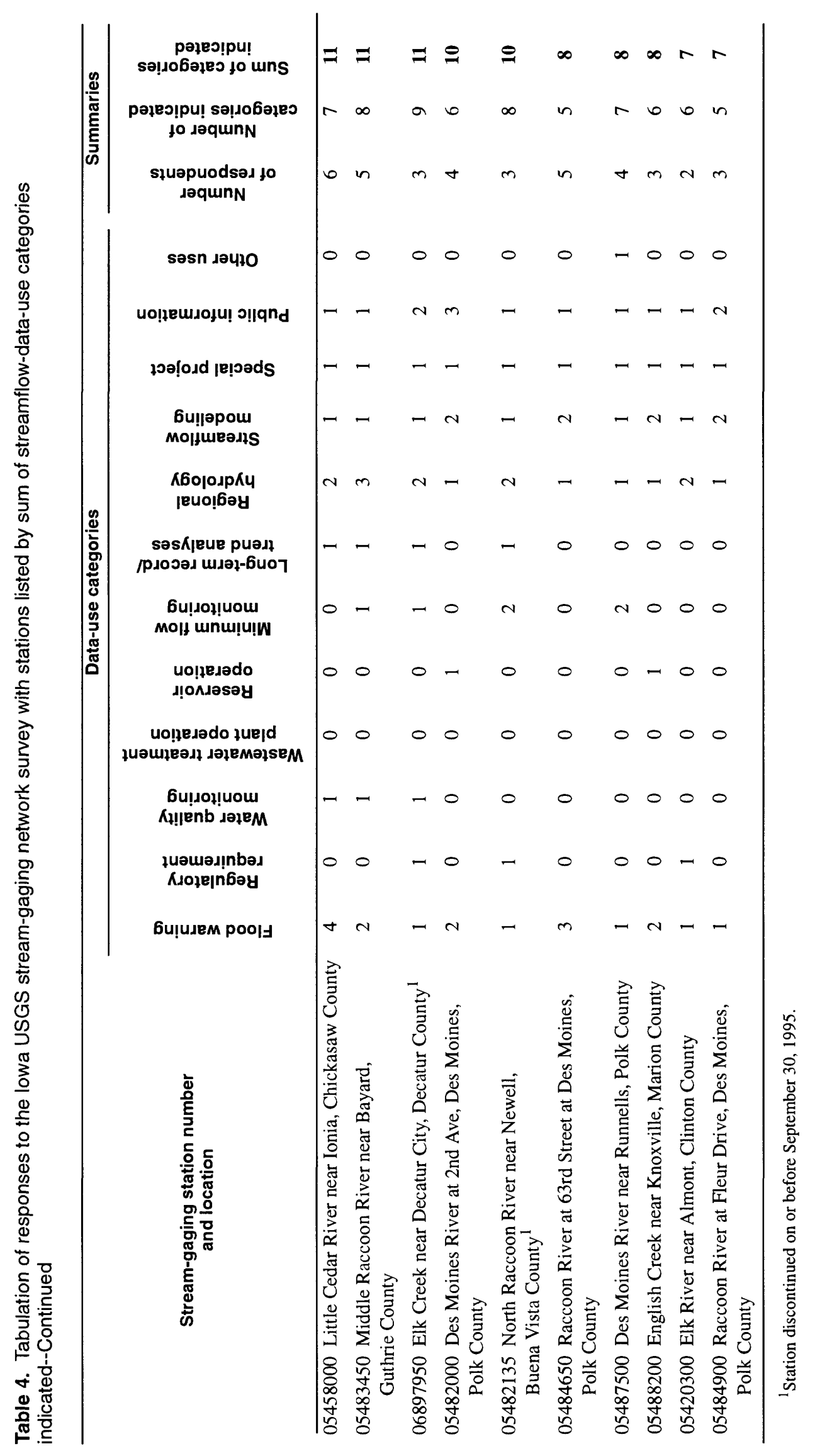

